Article received on 7 March 2013

Article accepted on 8 March 2013

UDC: $78.01 ; 050.489$ NEW SOUND

\title{
SECTIONS NEW WORKS AND INTERPRETATIONS IN THE LAST TWENTY YEARS OF THE NEW SOUND MAGAZINE AS THE INDICATORS OF TWO IMPORTANT PRINCIPLES IN MUSICOLOGICAL WORK
}

\author{
Mirjana Veselinović-Hofman* \\ University of Arts in Belgrade \\ Faculty of Music \\ Department of Musicology
}

\begin{abstract}
This item concerns the profile and the contribution of the sections New Works and Interpretations to the recognition of contemporary Serbian music, on the basis of how they have functioned during the past two decades of the International Magazine for Music New Sound. Thereby, these sections can be considered as representative of two crucial principles of the musicological process - analytical and interpretative. It is on the basis of each and on their mutual permeation that different genres of musicological texts originate.
\end{abstract}

Keywords: New Sound, new works, interpretations, views, musicological genre

Апстракт: У овом раду разматрају се физиономија и допринос рубрика Нова дела и Интерпретације афирмацији савремене српске музике, на темељу њиховог деловања током две деценије постојања Интернационалног часописа за музику Нови Звук. При томе се у проблемском смислу сагледавају као оличења два основна

\footnotetext{
* Author contact information: mvesel@eunet.rs

The paper was written within the project Identiteti srpske muzike u svetskom kulturnom kontekstu [Identities of Serbian Music in the World Cultural Context] by the Department of Musicology of the Faculty of Music in Belgrade, supported by the Ministry of Education, Science and Technological Development of the Republic of Serbia, under Reg, No. 177019.
} 
принципа музиколошког рада - аналитичког и интерпретативног, на чијој појединачној основи и међусобним прожимањима израстају различити жанрови музиколошког текста.

Кључне речи: Нови Звук, нова дела, интерпретације, погледи, музиколошки жанр

New Works and Interpretations are two key sections of the New Sound magazine that deal immediately with newly composed musical works. Working alongside one another, but each pursuant to its own unique conception, practice and goal, they conjointly embody the methodology of the musicological approach to music - not only contemporary! - that the magazine strives to affirm. This methodology includes, on the one hand, an analytical focus on an individual work, and on the other, on its problem positioning and interpretations. It covers, therefore, the range from types of individual presentations of new works to the superstructure of interpretative contextualizations. In that respect, the very titles of the sections are almost symbolic.

However, this does not mean that the New Works section is filled only with 'close readings' of new compositions, or that the Interpretations section is made up only of 'contexts without texts' - even when the contributors are not only musicologists, but also composers, performers, art historians or aestheticians: although at first one might expect them to advocate a strictly 'specialist' viewpoint, their perspectives are always wider and oriented in the methodologically 'opposite' direction. In other words, the items whose discourse naturally relies on the analytical sphere ${ }^{1}$ contain certain problem postulates, some theoretical observations, comparisons and evaluations, while the items whose discourse

1 E.g. Zoran Erić, Znakovi Srđana Hofmana kao pojmovnik upotrebe žive elektronike u procesu kreiranja realnog muzičkog vremena [Signs by Srđan Hofman as a Directory for the Use of Live Electronics in the Process of Creating Real Musical Time], Novi zvuk, 6, 1995, 97-101; Zoran Erić, Vlastimir Trajković: muzika za klavir [Vlastimir Trajković: Music for Piano], Novi zvuk, 9, 1997, 51-54; Vlastimir Trajković, S onu stranu međe moderna-postmoderna: Koncert za klavir i gudački orkestar Jugoslava Bošnjaka ili pouzdanje u princip muzikalnosti [Beyond the Boundary Modernism-Postmodernism: Concerto for Piano and String Orchestra by Jugoslav Bošnjak or Confidence in the Principle of Musicality], Novi zvuk, 15, 2000, 95-100; Milan Mihajlović, Pesme o zvezdama Svetlane Kresić [Pesme o zvezdama (Poems About Stars) by Svetlana Kresić], Novi zvuk, 18, 2001, 79-84; Svetlana Kresić, Pesme o zvezdama [Poems About Stars], Novi zvuk, 18, 2001, 85-87; Svetlana Kresić, AJ DI (ID) of Marsovci ili jednačina sa više nepoznatih [ID of Martians or Equation with Several Unknowns], Novi zvuk, 20, 2002, 87-90; Borislav Čičovački, Testije i kondiri - u potrazi za muzičkim ,iskopinama” [Testije i kondiri (Jugs and Stoups) - in Search of Music 'Artefacts'], Novi zvuk, 21, 2003, 81-86. Cf. Table 1! 
stems primarily from the theoretical and interpretative sphere ${ }^{2}$ include certain analytical notes and arguments. In truth, although one can only speak of musicologists' papers as written in specifically musicological genres, the items by other authors are nevertheless examples of making fundamental connections between factual insights and personal opinions.

Apart from presenting the individual compositional and technical particulars of the treated works, as well as their aesthetic premises and stylistic features, the musicological papers in the New Works section display a tendency to place these works not only in the context of the individual creative paths and creative dynamics of their authors, but also in the setting of the compositional practice, the surrounding artistic milieu, as well as the relevant historical heritage. At the same time, the material acquired through this musical, factual and historic research is the basis for shaping the individual musicological views of a work, mostly founded on interdisciplinary thinking. Diverse stimulations from various disciplines converge within these views - most often visual, literary and aesthetic ones, as well as the stimulations of a sociological or culturological nature. ${ }^{3}$ They are not, however, extensive elaborations, but a way of introducing a new work to readers which does not dwell just on a description, but also includes the concise articulation of the problem with the dimension of critical evaluation.

Therefore, in spite of not being large in scale, these papers clearly have well-defined genres, mostly as musicological 'miniatures' with problematization overtones. ${ }^{4}$ These texts, namely, display a consistent, causal and consequential permeation of the analytical and interpretative approaches, meaning that, typologically, they stand between the papers that otherwise - by focusing on detailed analytical examinations of a particular work or a group of related works - populate the Analyses section, and the papers published in the Interpretations section. That is to say: from the viewpoint of their general methodologi-

2 E.g. Miško Šuvaković, Mimezis mimezisa. Estetsko kao transgresivni element muzike [Mimesis of Mimesis. The Aesthetic as a Transgressive Element of Music], Novi zvuk, 10, 1997, 83-91; Nikola Šuica, Vladan Radovanović: Sazvežđa [Vladan Radovanović: Constellations], Novi zvuk, 12, 1998, 75-78; Marsel Kobason [Marcel Cobussen], Džon Zorn: dekonstrukcija i komprovizacija [John Zorn: Deconstruction and Comprovisation], Novi zvuk, 13, 1999, 51-60.

3 Cf. Mirjana Veselinović-Hofman, Međunarodna tribina kompozitora i časopis Novi zvuk: korelacija vidova predstavljanja srpske savremene muzike [International Review of Composers and the New Sound Magazine: Correlation of Types of Presentation of Contemporary Serbian Music], in: ...under (re)construction. Međunarodna tribina kompozitora 1992-2007, Vesna Mikić and Ivana Ilić (eds.), Belgrade, Udruženje kompozitora, 2007, 95-98.

4 A deviation from such a genre format can be found in papers by the authors who are not specialists in musicology. Cf. footnotes 1 and 2 . 
cal procedure, the majority of contributions to the New Works sections approach the genre of a musicological study, because in a compact form they demonstrate the relationship between the formalist-positivist and the contextual, whose types of manifestation and complexity represent one of the important hallmarks of genuine scientific studies. Still, as previously said, the New Works section of the magazine sometimes contains contributions in which the analytical component and the personal comments are fused in a certain musicologically 'casual', but valuable way, and there are also contributions where new compositions are presented in a more pronouncedly analytical sense, from the concrete aspects of form, harmony, compositional technique, media, etc. that distinguish them. Therefore they are included in the Analyses section. ${ }^{5}$ It is, thus, a type of contribution where the New Works and Analyses sections actually cooperate on a joint task - presenting new compositions! - but in two fundamentally different ways and with different intensities. ${ }^{6}$ This is understandable, because the concept of the Analyses section is not necessarily restricted to the latest production, or even contemporary music, since the goal of this segment is to demonstrate the application of chosen analytical concepts and methods using case studies from the entire history of music.

Within the described framework and in the described ways, eighty-eight compositions were treated in the New Works section up to and including the magazine's Issue $39 .{ }^{7}$ (Appendices: Table 1$)^{8}$

5 Summary of these papers can be found in the appendix New Works in the Analyses Section (Table 3).

6 More on ways of elaborating on newly created compositions and, generally, contemporary music as the common subject of all the sections in the New Sound magazine, in: Mirjana Veselinović-Hofman, Nova dela i časopis Novi zvuk - Novi zvuk kao karika institucionalnog ulančavanja u svetu savremene srpske muzike [New Works and the New Sound Magazine the New Sound as a Link in the Institutional Chain in the World of Contemporary Serbian Music], in: Tematski potencijali leksikografskih jedinica o muzičkim institucijama, Vesna Mikić, PhD, and Tijana Popović Mlađenović, PhD (eds.), Muzikološke studije - Zbornici radova, vol. 7, Belgrade, Katedra za muzikologiju, Fakultet muzičke umetnosti, 2009, 163170.

7 If we also include the new works dealt with from primarily the analytical or interpretative viewpoint in the appropriate sections - Analyses and Interpretations - the total amounts to ninety-eight works discussed in twenty years of the magazine's existence, and most of them belonged to the latest compositional production.

8 The table contains the title of each work, its author, the author of the item, the item's title, the magazine issue in which the item was published, year of publication and the numbers of the first and last pages of the item. Given that New Sound is published both in Serbian and in English, the table also contains translations of the titles, as well as the data on the publishing dynamics of the magazine in these languages. Namely, up to Issue 23, the issues were pub- 
This selection has been made from a production monitored yearly, and involving several sources: the International Review of Composers in Belgrade, ${ }^{9}$ the domestic concert repertoire with premieres and performances of awarded works, the programmes of certain world festivals of contemporary music, as well as domestic and foreign ensembles specialized in its performance. As a rule, all these sources offer an insight into the production of the current year or the year before as well, and so these are indeed the latest achievements. ${ }^{10}$ During that process, attention is paid predominantly to the compositional creation in Serbia. To a lesser extent but in the same manner, the selection includes recent compositions by foreign authors; more precisely, those who originated from the Serbian environment, but whose lives and professional careers are successfully progressing in musical cultures all over the world.

By implying a certain degree of contextual projection of a particular musical material, the New Works section is more closely related to the Interpretations section than to the Analyses section. Namely, like the New Works section, the Interpretations section establishes fundamental connections between the musical substance and its interpretation, but during the elaboration of these personal elucidations, a 'demonstrative' reaching for the analytical apparatus is not necessarily employed. Besides, although this section also presents musical works which are usually of the most recent production ${ }^{11}$, either as individual

lished simultaneously in the Serbian and English languages. Since Issue 24, the English version was published only online, up to Issue 31, which was published only in Serbian. The following issue, 32, was published only in English, and since Issue 33, only the English edition has been printed, and also uploaded to the Web, while the Serbian edition has been published only online. The reader is advised of the currently unavailable forms of certain issues by their being stricken through in this table.

9 It is an international festival of contemporary music, organized yearly since 1992. Except for the first one, held in Novi Sad and Sremski Karlovci, all the following Reviews have taken place in Belgrade.

10 The works, in fact, come under consideration for being presented as soon as the Editorial Board of the magazine receives both news about the works and the works themselves. For example, the work cvetić, kućica... [little flower, little house...] by Marko Nikodijević was written in 2009, but it was only in 2010 that it received the Gaudeamus Prize and the Second Prize at the Tansman Competition in Poland; hence it was presented in the New Works section two years after being composed, in the New Sound 38, II/2011. (cf. Table 1!) The most distant from the chronological determinant of the new works in the magazine are the works by Vlastimir Trajković: Zvona [Bells] (1974) and Koncert za klavir i orkestar u B-duru, op. 21 [Concerto for Piano and Orchestra in B-flat Major, Op. 21] (1990), to which Zoran Erić metaphorically referred as 'eternally new', and that is the reason why they were included in this section. (cf. Table 1!)

11 Cf. appendix The Interpretations section and the new works in it (Table 2). 
compositions or within a festival programme, ${ }^{12}$ these works are treated in this section primarily as incentives and encouragements for special interpretative considerations. Thus, these items deliberate on what might be the entire scale of problem areas of contemporary music, even music in general - compositional, aesthetic, performing, stylistic, culturological..., and hence this deliberation involves not only musicologists, but also authors from non-musicological professions, who sharpen their theoretical observations primarily from the standpoint of their disciplines. Therefore, the thematic range of the Interpretations section is quite diverse, including areas that are important and inexhaustibly open for contextual elaboration, such as e.g. time and space in the light of concrete compositional poetics (for example, S. Rachmaninoff, H. Rădulescu, A. Pärt), ${ }^{13}$ the inexpressibility of music, ${ }^{14}$, issues of mimesis, ${ }^{15}$ deconstruction and music, ${ }^{16}$ music and literature, ${ }^{17}$ the poetic and aesthetic issues of media and technology in compositional creation and performance, ${ }^{18}$ the stylistic view on compositional

12 Cf. Mirjana Veselinović-Hofman, Avangarda danas: odjeci avangarde. Svetski dani muzike '95 [The Avant-garde Today: Echoes of the Avant-garde. World Music Days '95], Novi zvuk, 6, 1995, 71-95; Ksenija Stevanović, Pandorina muzička kutija: 11. međunarodna tribina kompozitora $u$ Beogradu [Pandora's Music Box: 11 ${ }^{\text {th }}$ International Review of Composers in Belgrade], Novi zvuk, 20, 2002, 76-82; Ivana Medić, Letnji kurs iz kompozicije i interpretacije Karlhajnca Štokhauzena [The Stockhausen Composition and Interpretation Courses], Novi zvuk, 25, 2005, 29-35; Aleksandar Damnjanović, Srpska muzika na festivalu evropske muzike u Francuskoj [Serbian Music on the Festival of European Music in France], Novi zvuk, 26, 2005, 113-118. Cf. Table 2!

13 E.g. Arbo Valdma, Rahmanjinov: vremenska i prostorna (dez)orijentacija [Rachmaninoff: Spatial and Temporal (Dis)orientation], Novi zvuk, 2, 1993, 41-48; Hartmut Meler [Hartmut Möller], Vremenski konflikti - višestruka vremena [Zeikonflikte - Multiple Zeiten], Novi zvuk, 11, 1998, 43-55; Herman Sabe [Herman Sabbe], Muzika stvara vreme; muzika zahteva vreme [Music Makes Time; Music Takes Time], Novi zvuk, 17, 2001, 49-54. Cf. Table 2!

14 Ana Kotevska, Ne/izrecivo kao alternativa [The In/expressible as an Alternative], Novi zvuk, 10, 1997, 75-82. Cf. Table 2!

15 Miško Šuvaković, Mimezis mimezisa. Estetsko kao transgresivni element muzike [Mimesis of Mimesis. The Aesthetic as a Transgressive Element of Music], Novi zvuk, 10, 1997, 83-91. Cf. Table 2!

16 Marsel Kobasen [Marcel Cobussen], Džon Zorn: dekonstrukcija i komprovizacija [John Zorn: Deconstruction and Comprovisation], Novi zvuk, 13, 1999, 51-60; Džeraldina Fin [Geraldina Finn], Muzika, identitet i différance u slučaju Čarlsa Ajvza [Music, Identity and Différance in the Case of Charles Ives], Novi zvuk, 18, 2001, 51-64. Cf. Table 2!

17 Miloš Zatkalik, Nivoi muzikalizacije književnosti [Levels of the Musicalization of Literature], Novi zvuk, 12, 1998, 61-73. Cf. Table 2!

18 Tatjana Marković, Medij horskog „glasa“ kao stilski označitelj u opusu Konstantina Babića [The Medium of the Choir 'Voice' as a Stylistic Signifier in Konstantin Babić's Opus], Novi zvuk, 20, 2002, 61-69; Bris Žoli [Brice Joly], Ksenakisov UPIC [L’UPIC de 
and performing creation, ${ }^{19}$ (auto)poetic reflections, ${ }^{20}$ the social and ideological environment of Serbian sacred music during the crisis in the $1990 \mathrm{~s},{ }^{21}$ World Music ${ }^{22}$ and many more. ${ }^{23}$

The Interpretations section is closely related to the Views section, but the latter one, however, occurs only occasionally - mostly when it contains contributions that do not quite belong to the genre of interpretations, but deal with the act of expressing a particular attitude towards various phenomena and segments of musical life, their personal description and zooming, yet without the 'development section' which in terms of type and scope is typical of studies. Therefore, in this section - arranged as a separate segment five times in the previous thirty-nine issues of the magazine - such a view was directed to very dissimilar things, such as individual compositional creation, ${ }^{24}$ music as the constituent of customary social practice, ${ }^{25}$ the promotion of musical cultures as a form of co-

Xenakis], Novi zvuk, 21, 2003, 57-65; Bojana Cvejić, Autor kao producent - Kronos kvartet. U performativnim mutacijama sveta muzike [The Author as the Producer - The Kronos Quartet. In Performative Mutations of the World of Music], Novi zvuk, 22, 2003, 27-37. Cf. Table 2!

19 Dragana Stojanović-Novičić, Cool/Hot and Soft: Prolog, akcija i kadenca Petra Ozgijana [Cool/Hot and Soft: Petar Osghian's Prologue, Action and Cadence], Novi zvuk, 20, 2002, 70-75; Antonio Baldassare, 'They Play More Like Angels Than Like Men' - The Quatuour de Flonzaley and Considerations on its Performance Style, New Sound, 35, I/2010, 70-100; Anna Scott, Reinterpreting Michael Musgrave and Bernard D. Sherman's Performing Brahms: Early Evidence of Performance Style, New Sound, 37, I/2011, 75-79. Cf. Table 2!

20 Gerhard Štebler [Gerhard Stäbler], San. Nesan: nekoliko razmišljanja o komponovanju, sa primerima iz dela Gerharda Šteblera [Nicht Traum. Traum: Einige Überlegungen zum Komponieren mit Beispielen aus Werken Gerhard Stäblers], Novi zvuk, 6, 1995, 71-95. Cf. Table 2!

21 Miloje Nikolić, Ko udara tako pozno iliti o fenomenu nove srpske pravoslavne duhovne muzike devedesetih godina dvadesetog veka [Who Bangeth So Late or the Phenomenon of New Serbian Orthodox Sacred Music in the Last Decade of the Century], Novi zvuk, 15, 2000, 75-93. Cf. Table 2!

22 Dimitrije O. Golemović, World Music, Novi zvuk, 24, 2004, 41-47; Mladen Marković, World Contra Ethno... protiv kao i obično [World Contra Ethno... Against as Usual], Novi zvuk, 24, 2004, 48-51. Cf. Table 2!

23 Cf. Table 2.

24 E.g. in the text Ljubica Marić - istom rekom vremena [Ljubica Marić - By the Same River of Time] (Novi zvuk, 14, 1999, 31-41), Zorica Makević sheds light on the poetic of Lj. Marić, based on her works Archaia I for string trio (1992), Čudesni miligram [The Wondrous Milligram] for soprano and flute (1992), Archaia II for wind trio (1993) and Torso for piano trio (1996). Cf. Table 4!

25 Dimitrije Golemović, Uloga muzike u posmrtnim običajima Srbije i Crne Gore [The 
operation between magazines, ${ }^{26}$ categories of World Music, ${ }^{27}$ the relationship between the domains of the spiritual and the musical through the critical reception of a musicological-aesthetic publication. ${ }^{28}$

The sections dealt with in this item, however, were not always articulated individually in all the issues of the New Sound. Exceptions occur when the contributions belong mainly to the type of the study, but with genre stresses that are 'destabilizing', distinguishing and different, yet not decidedly defining. This will typically happen in some thematic issues of the magazine - probably because such issues naturally encourage and, in some way, release personal interpretative contextualizations as the specific layer of superstructure in studies. Therefore, in thematic issues, such texts are joined in the Core Issue section. Such is the case, for instance, in the issues dedicated to the spiritual music of the region of the Balkans $(16,2000)$, to the ballad (30, II/2007), to improvisation (32, II/2008) and to the metamorphosis of the musical-stage medium today (36, II/2010). Still, the New Works section survives independently in all these issues. And the issues whose themes are music and Futurism (34, II/2009) and contemporary music at the periphery $(38, \mathrm{II} / 2011)$ also contain the Interpretations section as a separate unit. Ultimately, all this confirms and supports contextual freedom and unconventionality in shaping a contemporary musicological text, which is in turn immediately related to the flexibility of the sections' content and form.

Even so, the contributions in the sections New Works and Interpretations, as well as in the Views segment, related to the latter, affirm the contemporary processes of musicological thinking and key procedures in the currently prevalent efforts of musicological elaboration in Serbia and abroad. Because, apart from domestic contributors, a large number of foreign authors write for these sections, which contributes significantly to bilateral acknowledgment, gaining mutual insights into musicological practice and results and, thus, the recognition of our musicological discourse in a conceivably broad geographical and culturological space - first of all, thanks to the magazine being published in English $^{29}$ and distributed in musical environments around the world.

Role of Music in Funeral Rites in Serbia and Montenegro], Novi zvuk, 14, 1999, 43-50. Cf. Table 4 !

26 Anders Bejer [Anders Beyer], Naš san o savezu [Our Dream of an Alliance], Novi zvuk, 25, 2005, 37-48. Cf. Table 4!

27 Iva Nenić, World Music: od tradicije do invencije [World Music: From Tradition to Invention], Novi zvuk, 27, 2006, 43-54. Cf. Table 4!

28 Mirjana Veselinović-Hofman, On Rethinking the Relationship Between Spirituality and Music - Marcel Cobussen: Thresholds..., New Sound, 34, II/2009, 115-120. Cf. Table 4!

29 Cf. footnote 8 ! 
Of course, besides demonstrating individual musicological styles and thus forming a picture of various possibilities and ways of presenting new compositions and subjects mainly from the domain of contemporary music, these sections contribute to the promotion of their own topics. Thereat, they have an additional responsibility, since they mostly contain the first papers ever published on the chosen newly composed works, as well as their first completely personal interpretative theoretical reception, shaped in an either musicological or non-musicological manner. With these first presentations, both sections New Works and Interpretations - mark the beginning of musicological dealing with the works treated in them. They not only introduce these works and their theoretical connotations and contextualizations into the realm of potential musicological interests and debates, but also give a kind of first proposal for the analytical interpretation and the direction of the problem deliberations that later may follow. Certainly, that proposal can later be accepted and developed, or disputed by giving arguments to different opinions. In any case, it is verifiable in principle and acoustically, given that the works in question are released on the accompanying compact discs. ${ }^{30}$ And this opens the possibility for them to become an object of new interest among performers at home and abroad.

Interestingly enough, while contributing to the New Works and Interpretations sections, certain musicologists have developed particular affinities for the music of certain composers. ${ }^{31}$ Thus, they observe the new works of these authors through the delicate nuances of their poetic realizations, and from the perspectives of their own problem insights. This often results in metaphorically rich, aesthetically well-founded and literarily shaped papers, built upon analytical argumentations that are stable and elaborated, but used unobtrusively.

The New Works and Interpretations sections thus continuously produce genuine musicological literature, chiefly on contemporary Serbian music, and hence they are crucial to the national musical historiography. They also put forward concrete facts of various profiles - analytical and historical, educational and descriptive - but also connotative readings, orientations and creations. These sections achieve that goal primarily as individual units, each within the domain of their own particulars, and then conjointly, whereby each includes elements of the other, as we have seen. From that perspective, in the last twenty years of the magazine's existence, the New Works and Interpretations sections became the

30 Cf. ibid.

31 For example, in their constant preoccupation with the latest compositional production in Serbia and abroad, Zorica Premate is particularly inclined towards the opus of Zoran Erić, while Vesna Mikić is singularly interested in the works by Srđan Hofman, as well as Serbian women composers living abroad (e.g. Milica Paranosić). Cf. Table 1! 
incarnation of two methodological poles that represent pillars of musicological research. And both of these pillars, by variously projected bridges, reach for each other.

Translated by Goran Kapetanović

\section{LITERATURE}

Veselinović-Hofman, Mirjana: Međunarodna tribina kompozitora i časopis Novi zvuk: korelacija vidova predstavljanja srpske savremene muzike, in: ...under (re)construction.

Međunarodna tribina kompozitora 1992-2007, Vesna Mikić and Ivana Ilić (eds.), Belgrade, Udruženje kompozitora, 2007, 95-98.

Veselinović-Hofman, Mirjana: Nova dela i časopis Novi zvuk - Novi zvuk kao karika institucionalnog ulančavanja u svetu savremene srpske muzike, in: Tematski potencijali leksikografskih jedinica o muzičkim institucijama, Vesna Mikić, $\mathrm{PhD}$, and Tijana Popović Mlađenović, PhD (eds.), Muzikološke studije - Zbornici radova, vol. 7, Belgrade, Katedra za muzikologiju, Fakultet muzičke umetnosti, 2009, 163-170.

Mikić, Vesna and Ilić, Ivana (eds.): ....under (re)construction. Međunarodna tribina kompozitora 1992-2007, Belgrade, Udruženje kompozitora, 2007.

Novi zvuk, Internacionalni časopis za muziku, 1-31, 1993-2008:

articles from the section Nova dela (stated in Table 1);

- Interpretacije (stated in Table 2);

- Analize (stated in Table 3);

- Pogledi (stated in Table 4)

New Sound, International Magazine for Music, 32-39, 2008-2012: articles from the section New Works (stated in Table 1);

- Interpretations (stated in Table 2);

- Analyses (stated in Table 3);

- Views (stated in Table 4)

\section{APPENDICES:}

\section{Table 1}

The New Works section

\section{Table 2}

The Interpretations section and the new works in it

\section{Table 3}

New works in the Analyses section

\section{Table 4}

Items in the Views section 


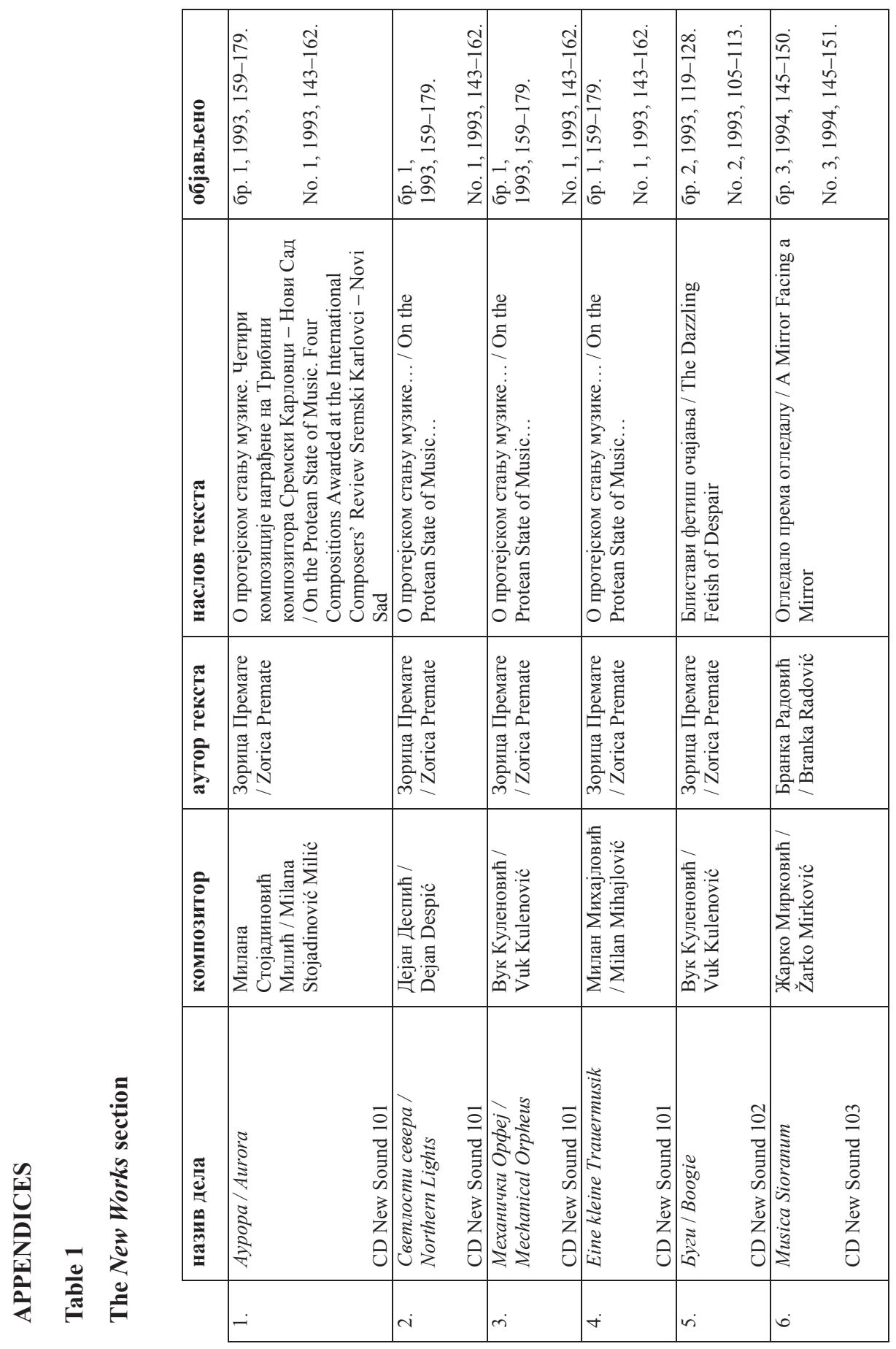


Veselinović-Hofman, M.: Sections New Works and Interpretations ... (114-145)

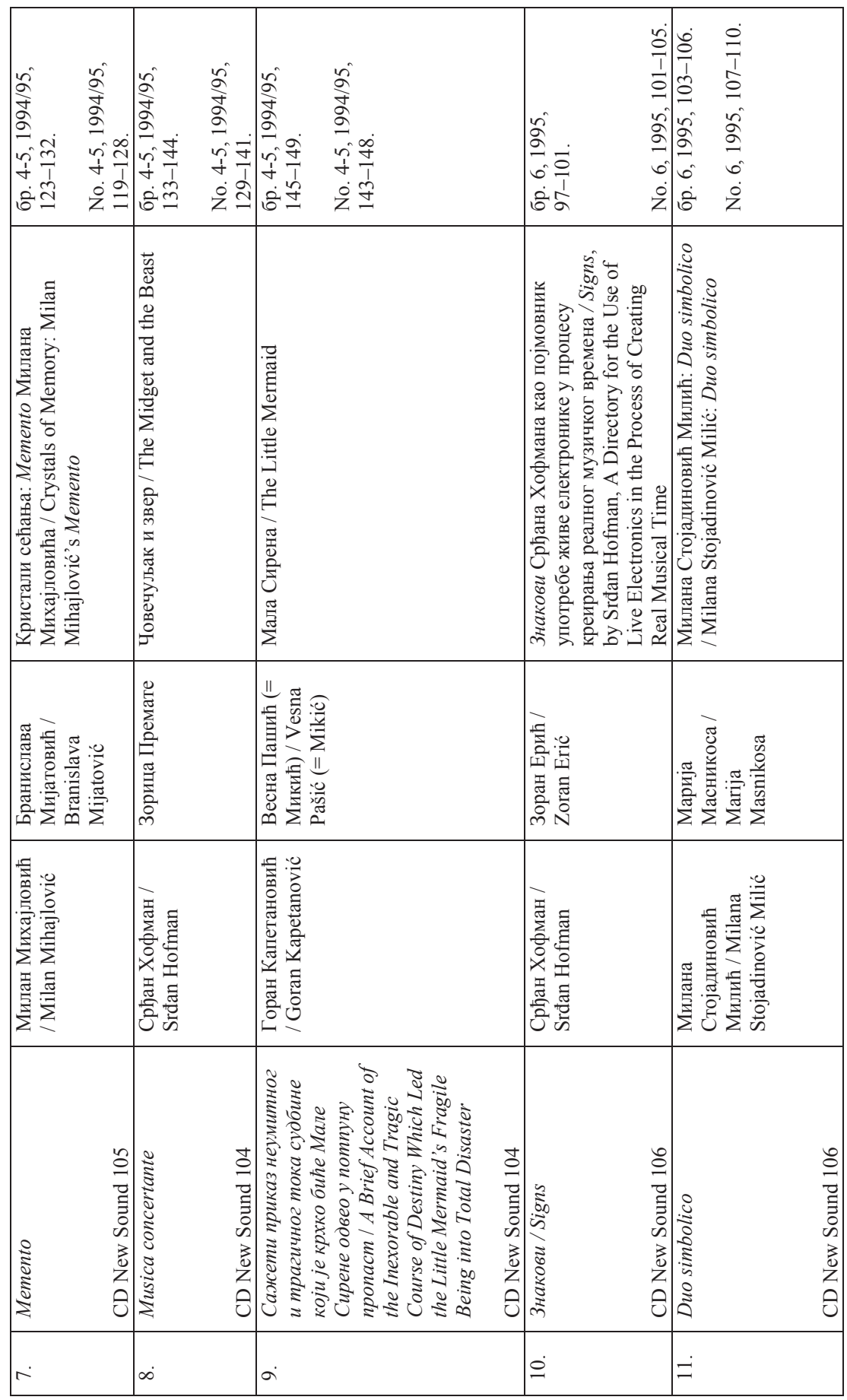




\begin{tabular}{|c|c|c|c|c|c|c|c|c|c|c|c|c|}
\hline 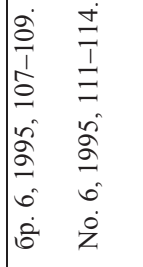 & & 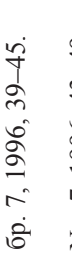 & 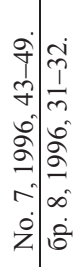 & 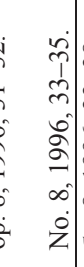 & $\begin{array}{l}\infty \\
0 \\
0 \\
m \\
0 \\
0 \\
2 \\
2 \\
\infty \\
\infty \\
\dot{\theta}\end{array}$ & 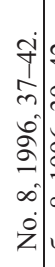 & $\begin{array}{l}\text { yं } \\
\text { के } \\
\text { के } \\
\text { aे } \\
\infty \\
\infty \\
\text { के }\end{array}$ & 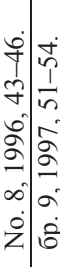 & 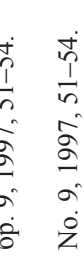 & 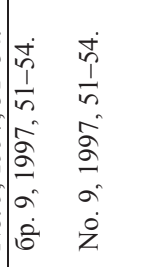 & 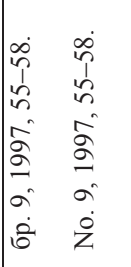 & 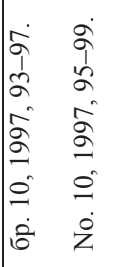 \\
\hline 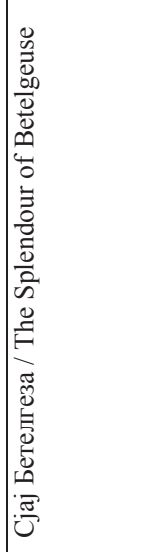 & & 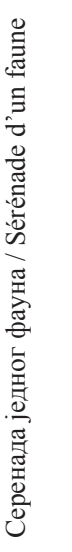 & 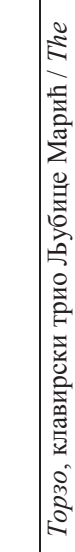 & 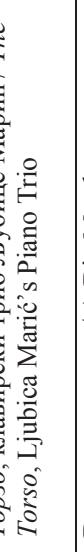 & 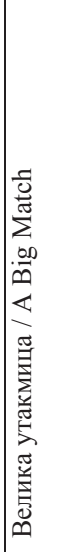 & & 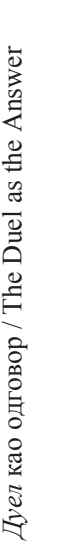 & & 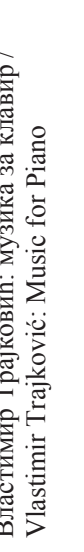 & 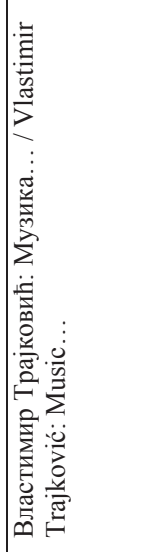 & 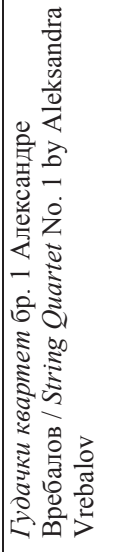 & 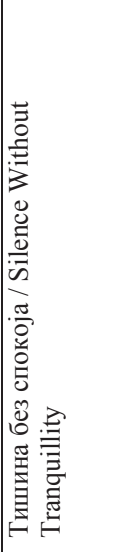 \\
\hline 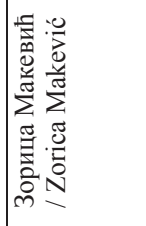 & & 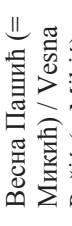 & 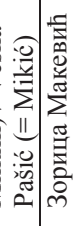 & 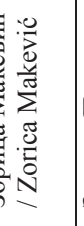 & 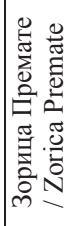 & & 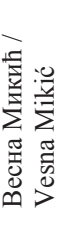 & & 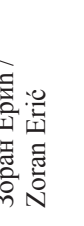 & 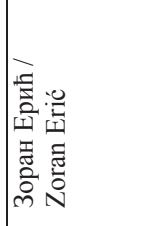 & 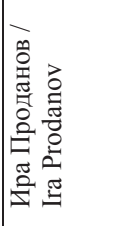 & 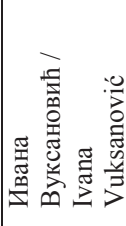 \\
\hline 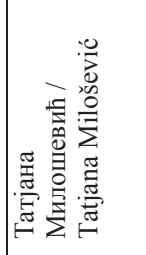 & & 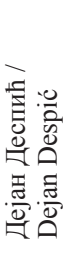 & - & $\sum_{0}^{0}$ & 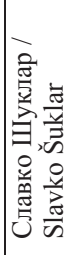 & & 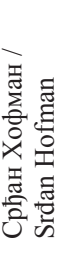 & & 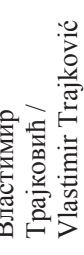 & 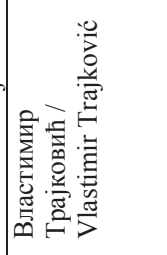 & 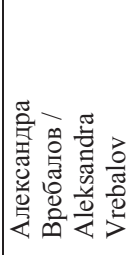 & 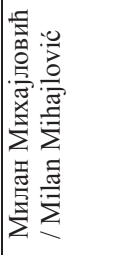 \\
\hline 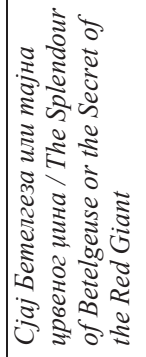 & $\begin{array}{ll}8 \\
0 \\
- \\
\vdots \\
0 \\
0 \\
3 \\
0 \\
2 \\
0 \\
0\end{array}$ & 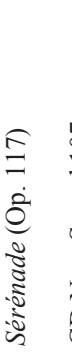 & \begin{tabular}{c|c} 
& \\
0 & \\
0 & \\
$\vdots$ & 0 \\
0 & 0 \\
0 & 0 \\
3 & 0 \\
0 & 0 \\
$z$ & 0 \\
0 & 0 \\
0 & 0 \\
0 & 0
\end{tabular} & 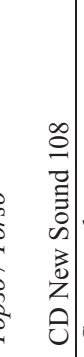 & 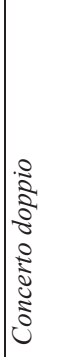 & $\begin{array}{c}\infty \\
0 \\
- \\
\vdots \\
0 \\
0 \\
3 \\
0 \\
0 \\
0 \\
0 .\end{array}$ & 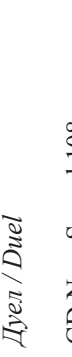 & 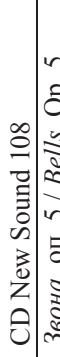 & 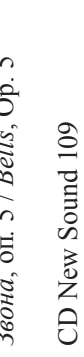 & 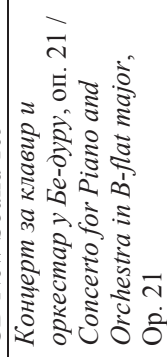 & 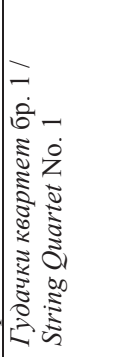 & $\begin{array}{l}0 \\
\bar{Z} \\
\overline{0} \\
0 \\
0 \\
3 \\
3 \\
0\end{array}$ \\
\hline & & $\ddot{\Omega}$ & \pm & & 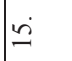 & & $\stackrel{0}{0}$ & $\triangle$ & $\Xi$ & $\infty$ & 2 & $\pi$ \\
\hline
\end{tabular}




\begin{tabular}{|c|c|c|c|c|c|c|c|}
\hline 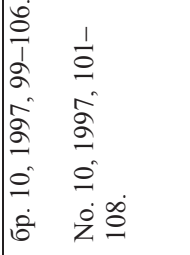 & $\begin{array}{l}\hat{1} \\
0 \\
\hat{a} \\
\hat{a} \\
0 \\
0 \\
\dot{0} \\
\dot{0}\end{array}$ & 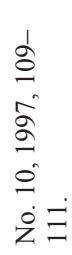 & 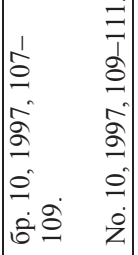 & 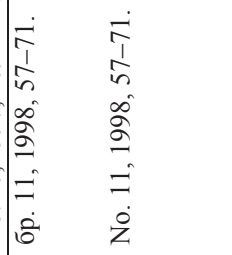 & 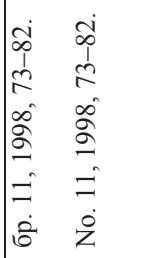 & 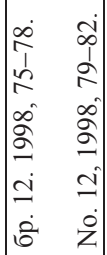 & 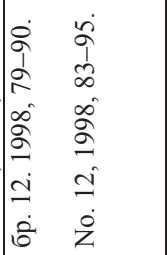 \\
\hline 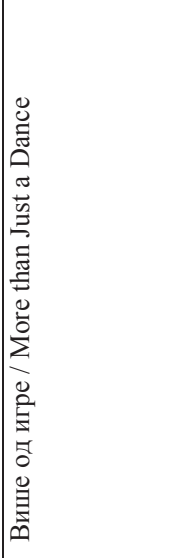 & 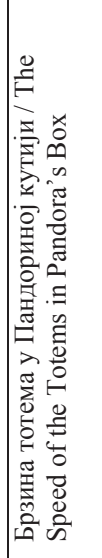 & & 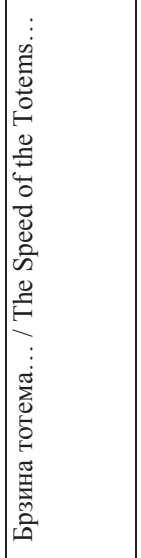 & 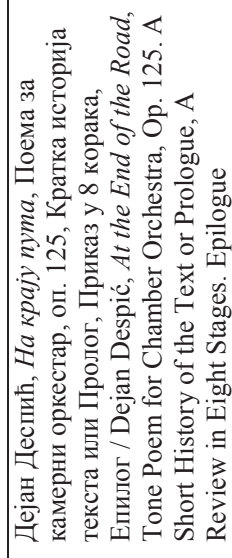 & 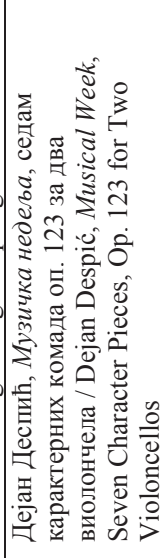 & 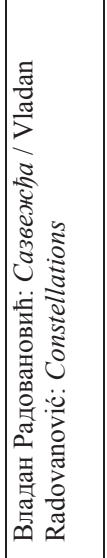 & 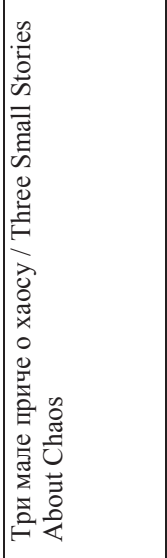 \\
\hline 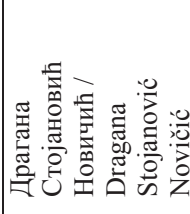 & 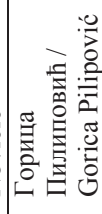 & & 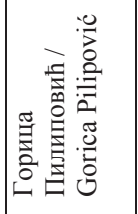 & 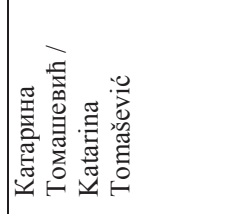 & 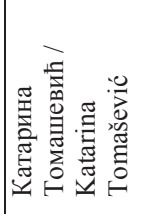 & 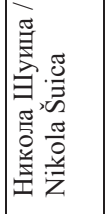 & 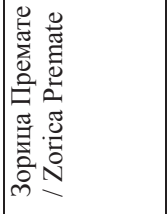 \\
\hline 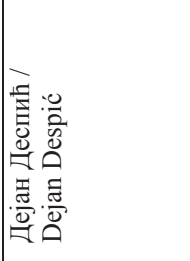 & 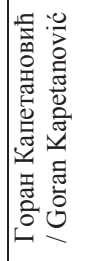 & & 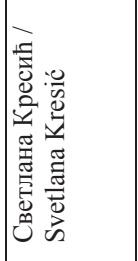 & 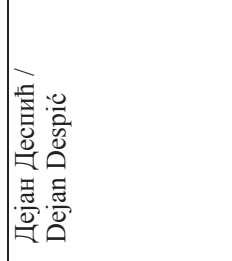 & 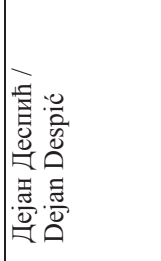 & 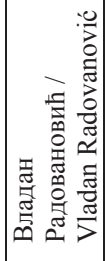 & 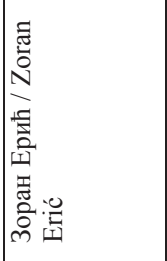 \\
\hline 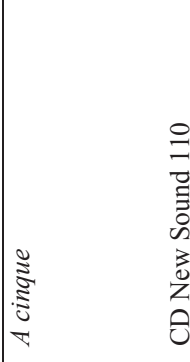 & $\frac{\widetilde{\Xi}}{\widetilde{J}}$ & $\begin{array}{l}\circ \\
\vdots \\
\bar{\Xi} \\
\vdots \\
0 \\
z \\
0 \\
z \\
0\end{array}$ & 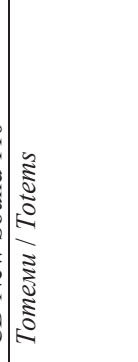 & 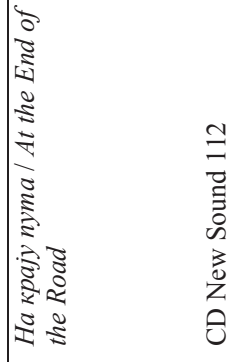 & 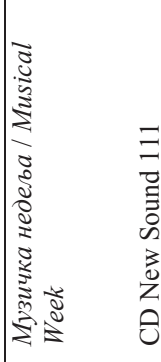 & 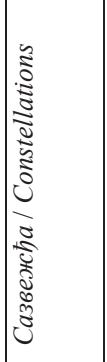 & 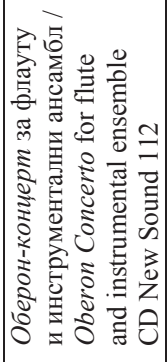 \\
\hline$\vec{\sim}$ & $\widetilde{\sim}$ & & di & $\stackrel{\sim}{\sim}$ & Ni & $\sim$ & $\sim$ \\
\hline
\end{tabular}




\begin{tabular}{|c|c|c|c|c|c|c|c|c|c|}
\hline 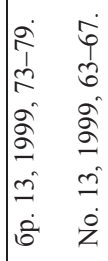 & & 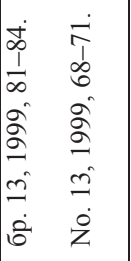 & 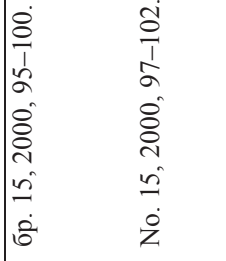 & 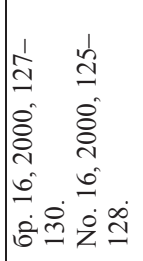 & 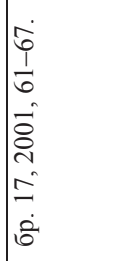 & 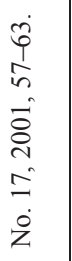 & 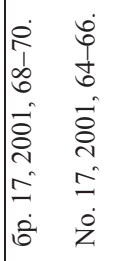 & 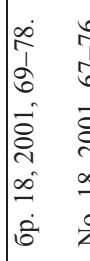 & \\
\hline 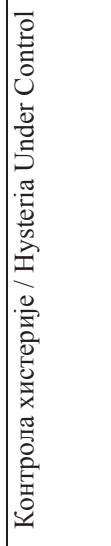 & & 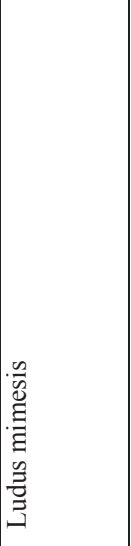 & 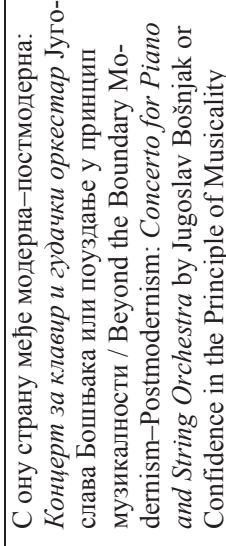 & 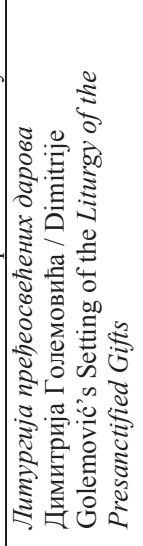 & 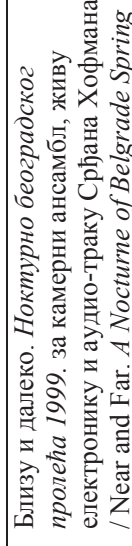 & 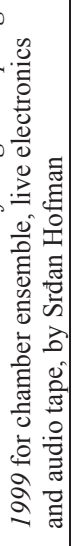 & 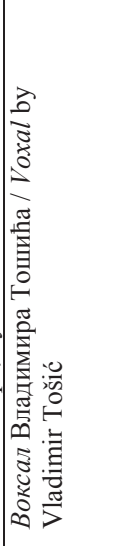 & 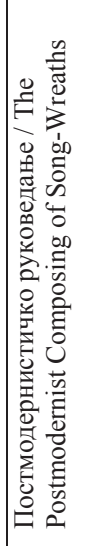 & \\
\hline 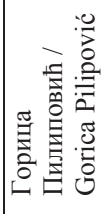 & & 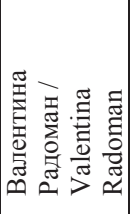 & 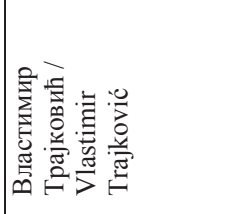 & 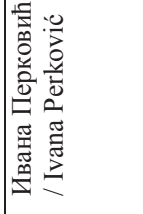 & 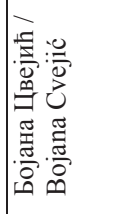 & & 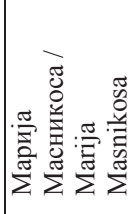 & 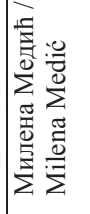 & \\
\hline 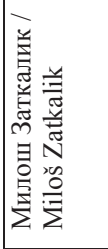 & & 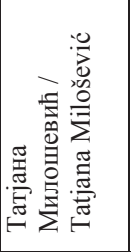 & 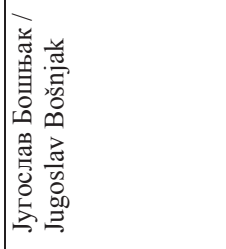 & 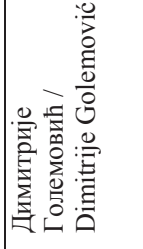 & 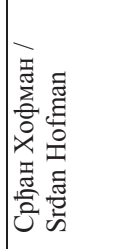 & & 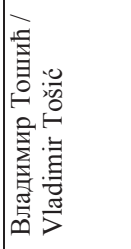 & 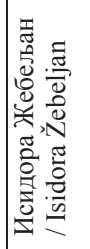 & \\
\hline 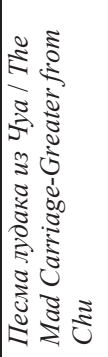 & $\begin{array}{l}0 \\
\Xi \\
0 \\
\vdots \\
0 \\
0 \\
3 \\
0 \\
z \\
z \\
0 .\end{array}$ & 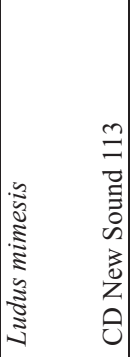 & 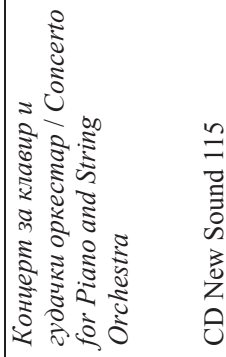 & 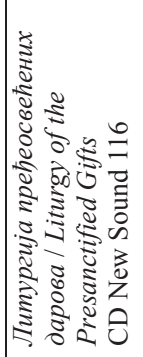 & 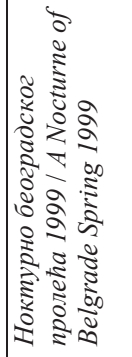 & $\begin{array}{l}1 \\
\Xi \\
\bar{z} \\
\Xi \\
0 \\
0 \\
3 \\
0 \\
z \\
0 \\
0\end{array}$ & 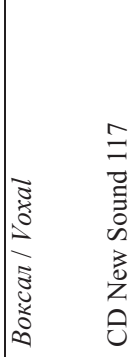 & 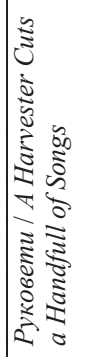 & $\begin{array}{l}\infty \\
= \\
\overline{0} \\
0 \\
0 \\
0 \\
0 \\
0 \\
0 \\
0\end{array}$ \\
\hline$\stackrel{\infty}{i}$ & & $\stackrel{\sim}{*}$ & $m$ & $\bar{m}$ & $m$ & & $m$ & $m$ & \\
\hline
\end{tabular}




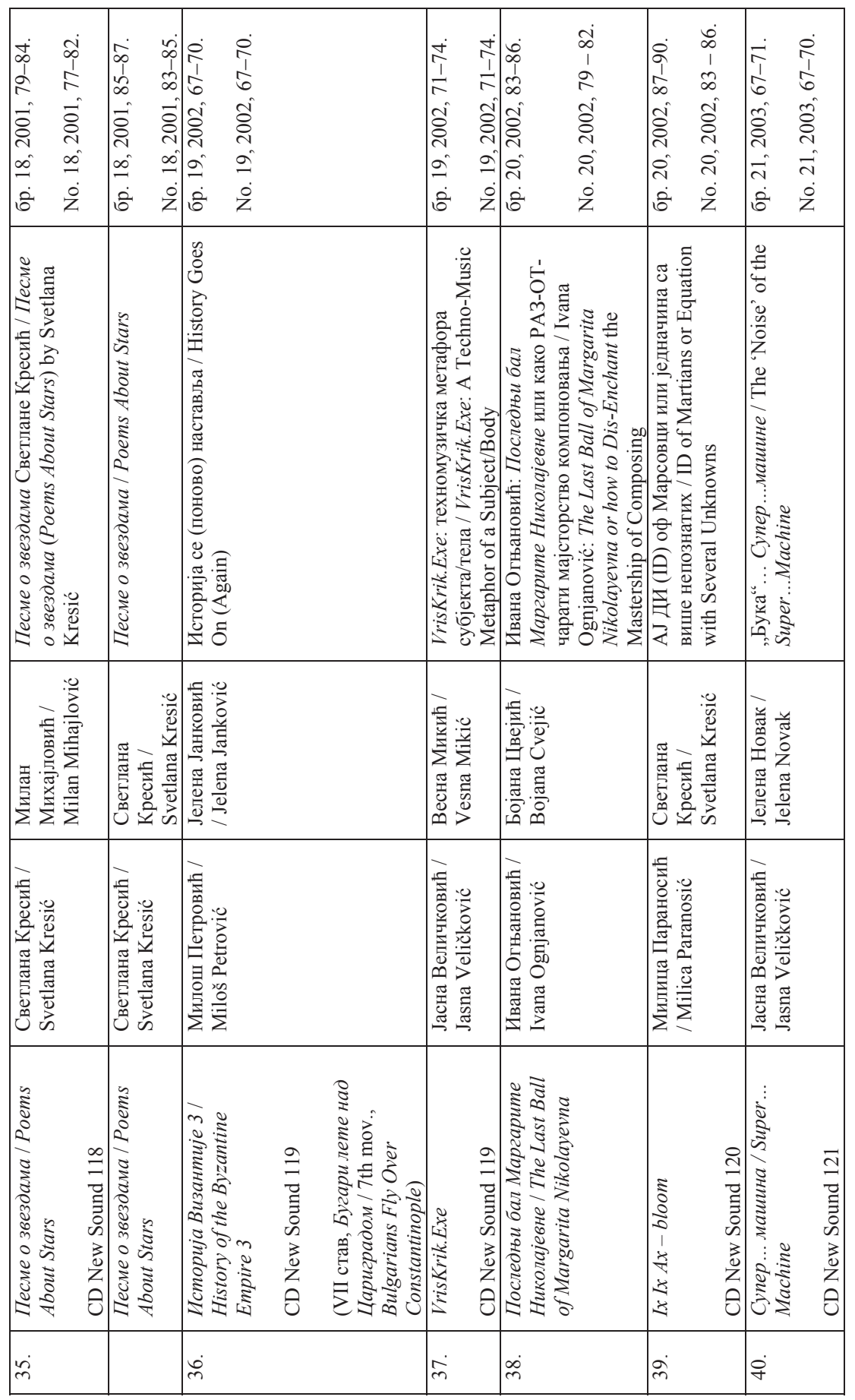




\begin{tabular}{|c|c|c|c|c|c|c|}
\hline 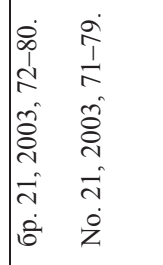 & 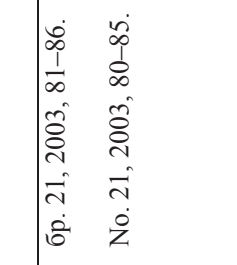 & 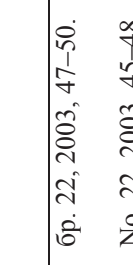 & & 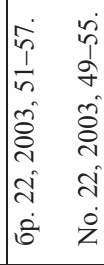 & 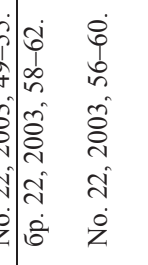 & 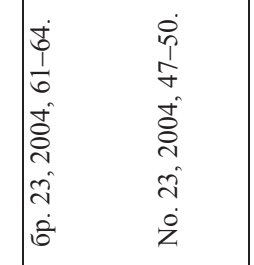 \\
\hline 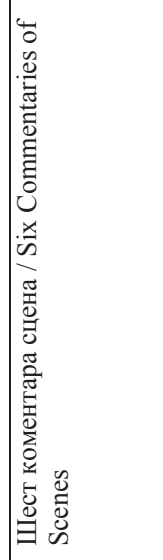 & 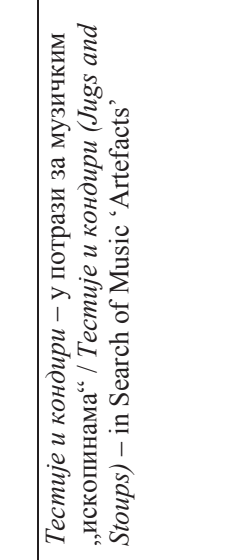 & 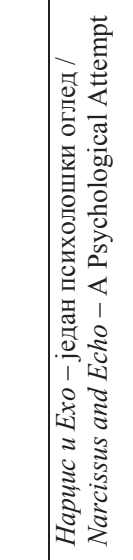 & & 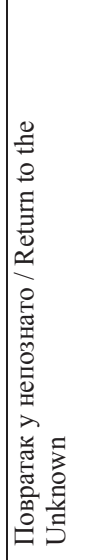 & 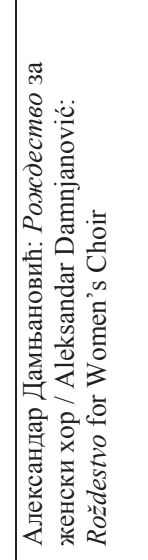 & 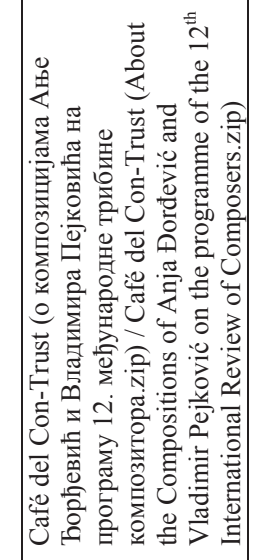 \\
\hline 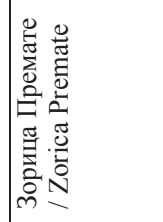 & 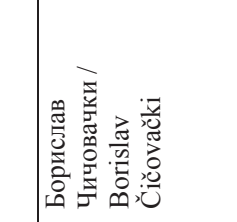 & 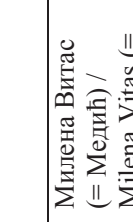 & & 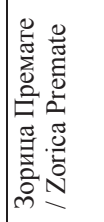 & 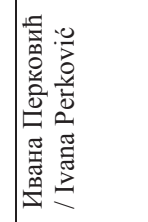 & 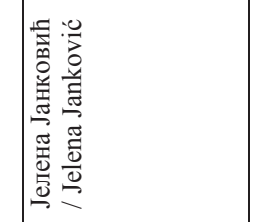 \\
\hline 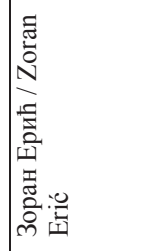 & 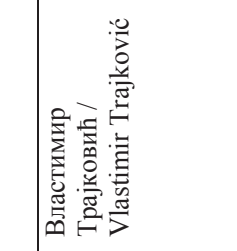 & 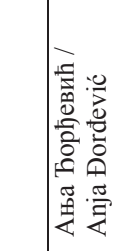 & & 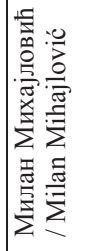 & 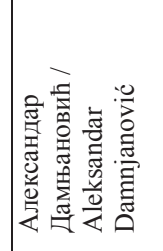 & 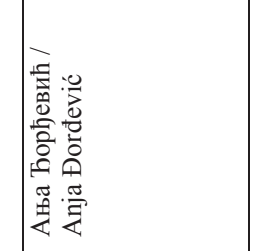 \\
\hline 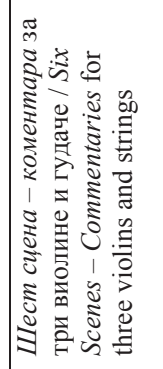 & 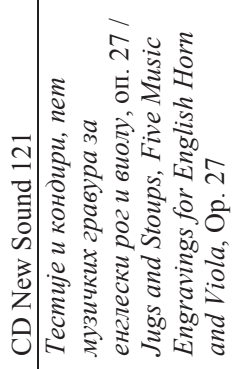 & 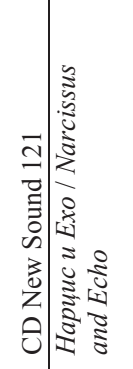 & 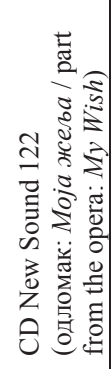 & 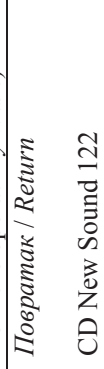 & 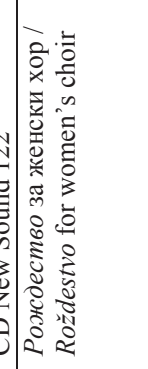 & 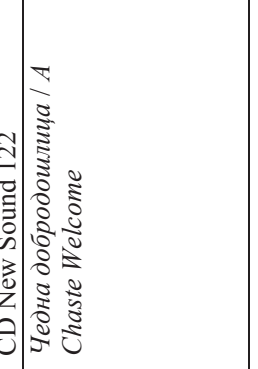 \\
\hline & fi & q & & |ষ & $\ddot{q}$ & | \\
\hline
\end{tabular}


Veselinović-Hofman, M.: Sections New Works and Interpretations ... (114-145)

\begin{tabular}{|c|c|c|c|c|c|c|c|c|c|c|}
\hline 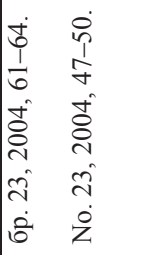 & 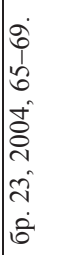 & 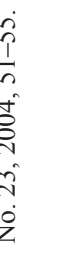 & 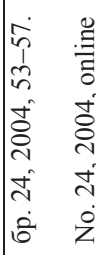 & & 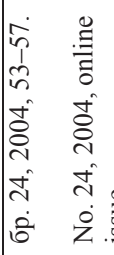 & & 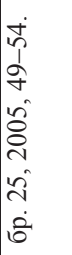 & 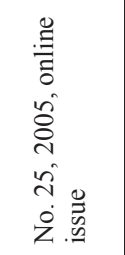 & 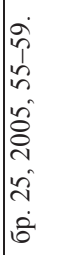 & 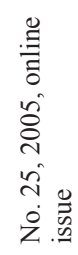 \\
\hline 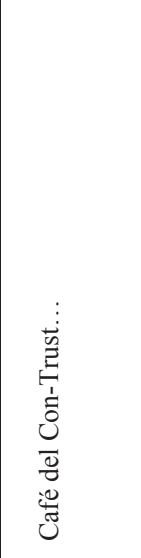 & \multicolumn{2}{|c|}{ 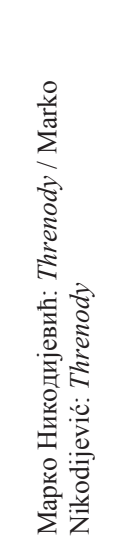 } & \multicolumn{2}{|l|}{ 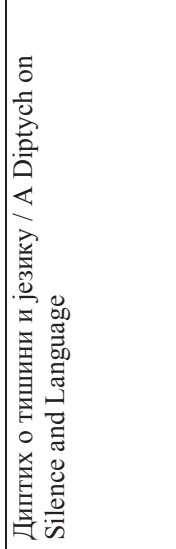 } & \multicolumn{2}{|l|}{ 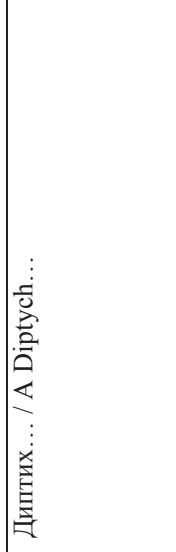 } & \multicolumn{2}{|c|}{ 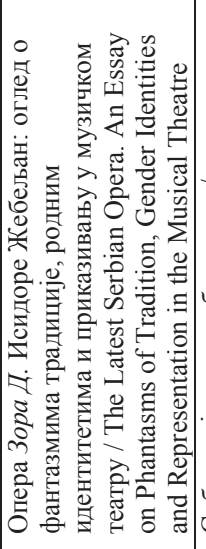 } & \multicolumn{2}{|c|}{ 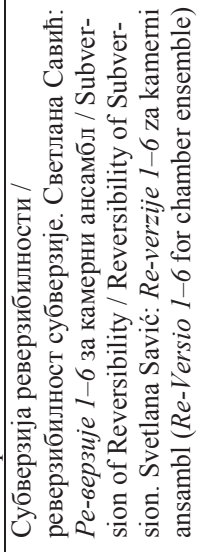 } \\
\hline 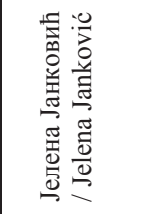 & & 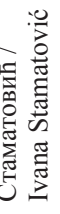 & 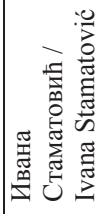 & & 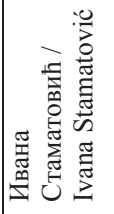 & & 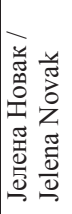 & & 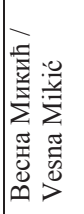 & \\
\hline 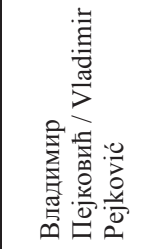 & 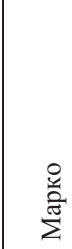 & 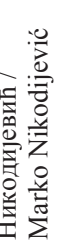 & 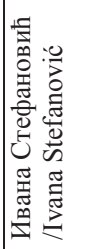 & & 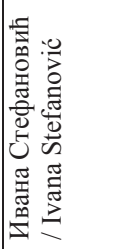 & & 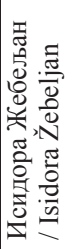 & & 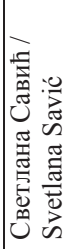 & \\
\hline 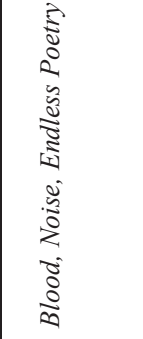 & 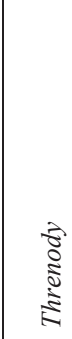 & $\begin{array}{l}\tilde{3} \\
\bar{z} \\
0 \\
0 \\
0 \\
3 \\
0 \\
z \\
0\end{array}$ & 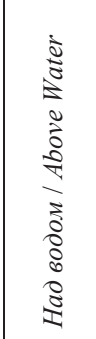 & $\begin{array}{l}- \\
\bar{Z} \\
\overline{0} \\
0 \\
3 \\
0 \\
0\end{array}$ & 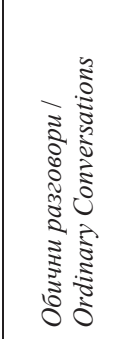 & 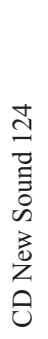 & 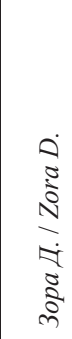 & & 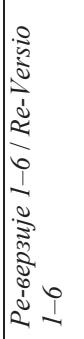 & 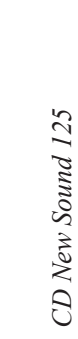 \\
\hline 于 & 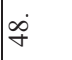 & & f & & $n$ & & $\bar{n}$ & & in & \\
\hline
\end{tabular}




\begin{tabular}{|c|c|c|c|c|c|c|c|c|}
\hline 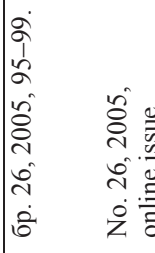 & & & 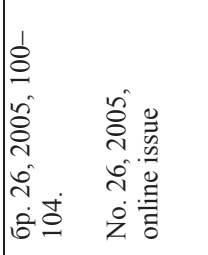 & & 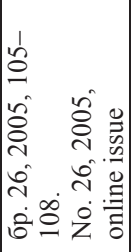 & 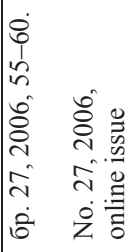 & & 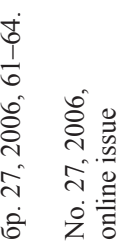 \\
\hline 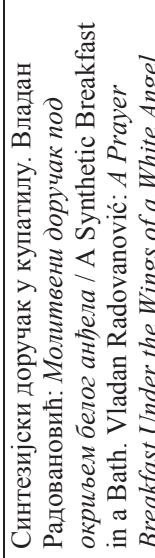 & & & 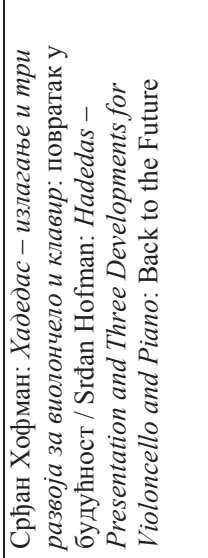 & & 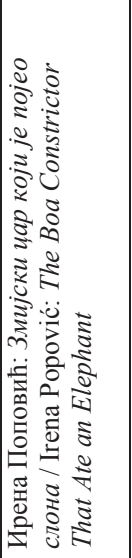 & 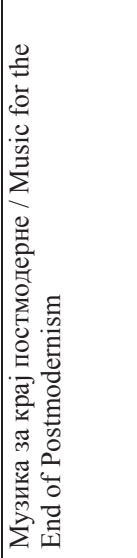 & & 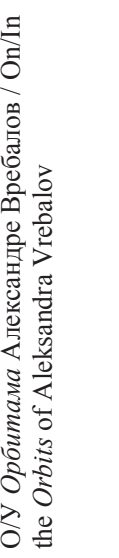 \\
\hline 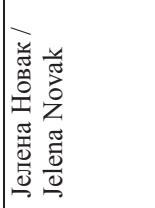 & & & 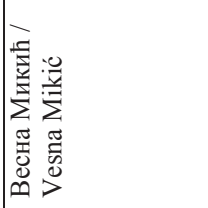 & & 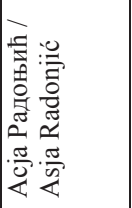 & 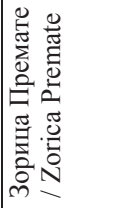 & & 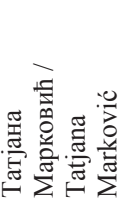 \\
\hline 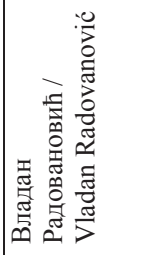 & & & 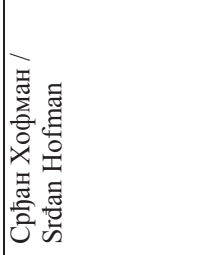 & & 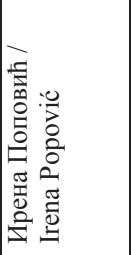 & 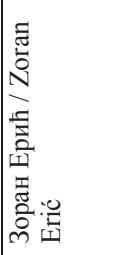 & & 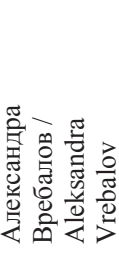 \\
\hline 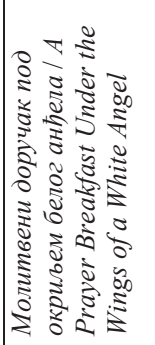 & 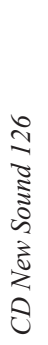 & 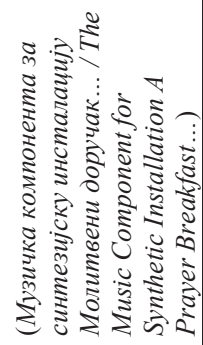 & 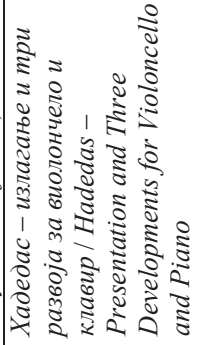 & 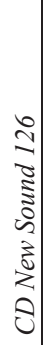 & 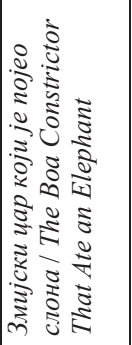 & 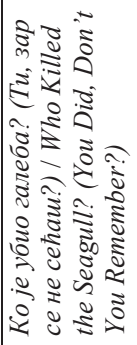 & 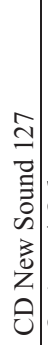 & 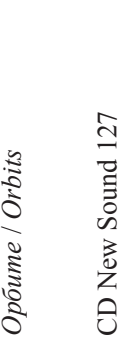 \\
\hline in & & & 吕 & & in & in & & in \\
\hline
\end{tabular}


Veselinović-Hofman, M.: Sections New Works and Interpretations ... (114-145)

\begin{tabular}{|c|c|c|c|c|c|c|c|c|c|c|c|}
\hline 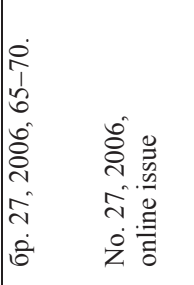 & \multicolumn{2}{|c|}{ 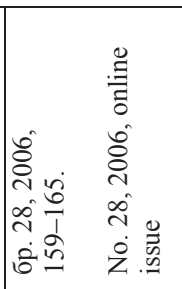 } & \multicolumn{2}{|c|}{ 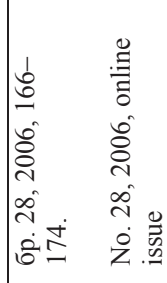 } & \multicolumn{2}{|c|}{ 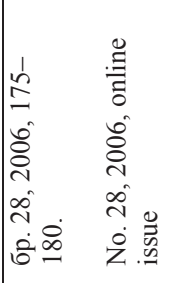 } & \multicolumn{2}{|c|}{ 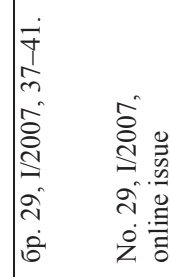 } & \multicolumn{3}{|c|}{ 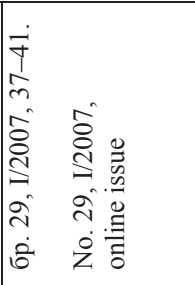 } \\
\hline 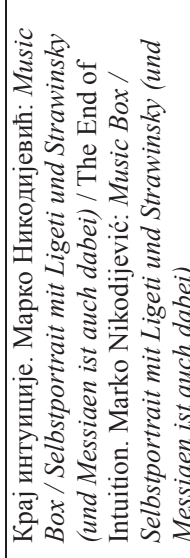 & 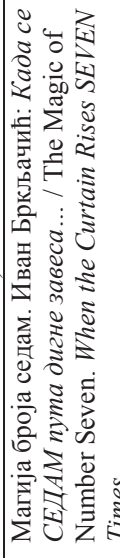 & & 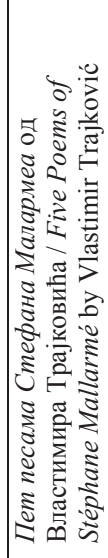 & & 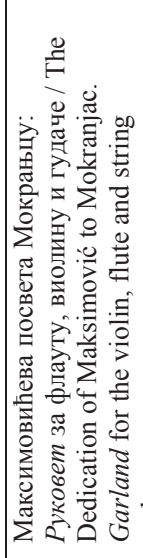 & & 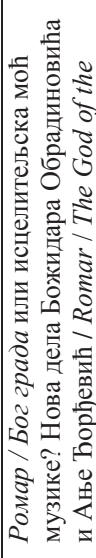 & 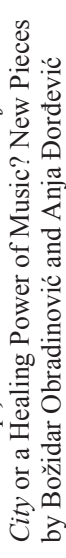 & 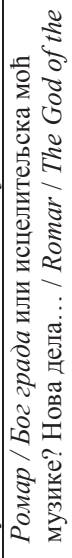 & 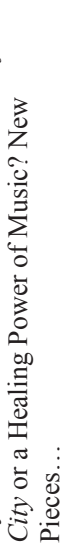 & \\
\hline 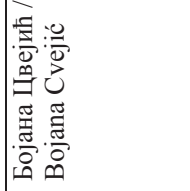 & 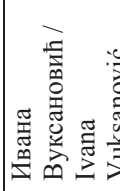 & & 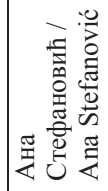 & & 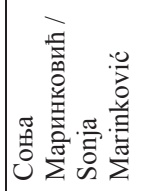 & & 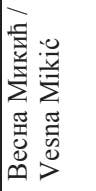 & & 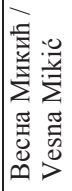 & & \\
\hline 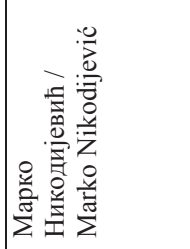 & 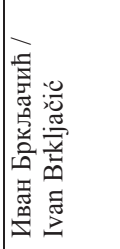 & & 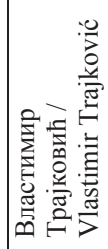 & & 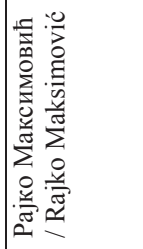 & & 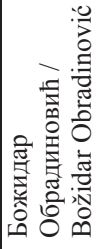 & & 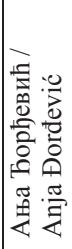 & & \\
\hline 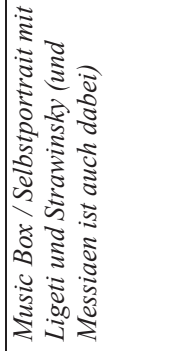 & 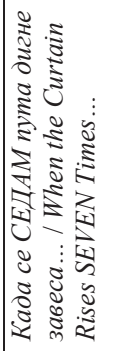 & 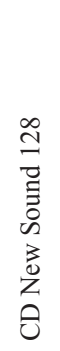 & 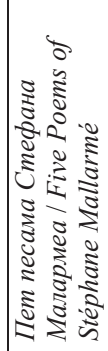 & 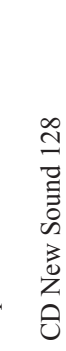 & 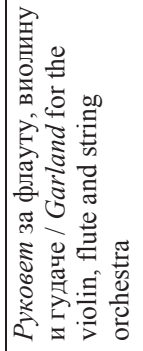 & 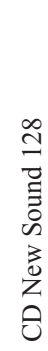 & 2 & $\begin{array}{l}\text { సे } \\
\overline{0} \\
\overline{0} \\
0 \\
3 \\
0 \\
z \\
0\end{array}$ & 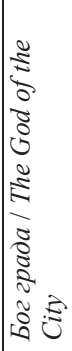 & 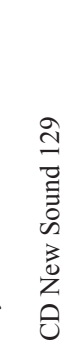 & 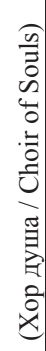 \\
\hline$\stackrel{\infty}{\circ}$ & in & & 0 & & $\bar{\sigma}$ & & 6 & & 10 & & \\
\hline
\end{tabular}




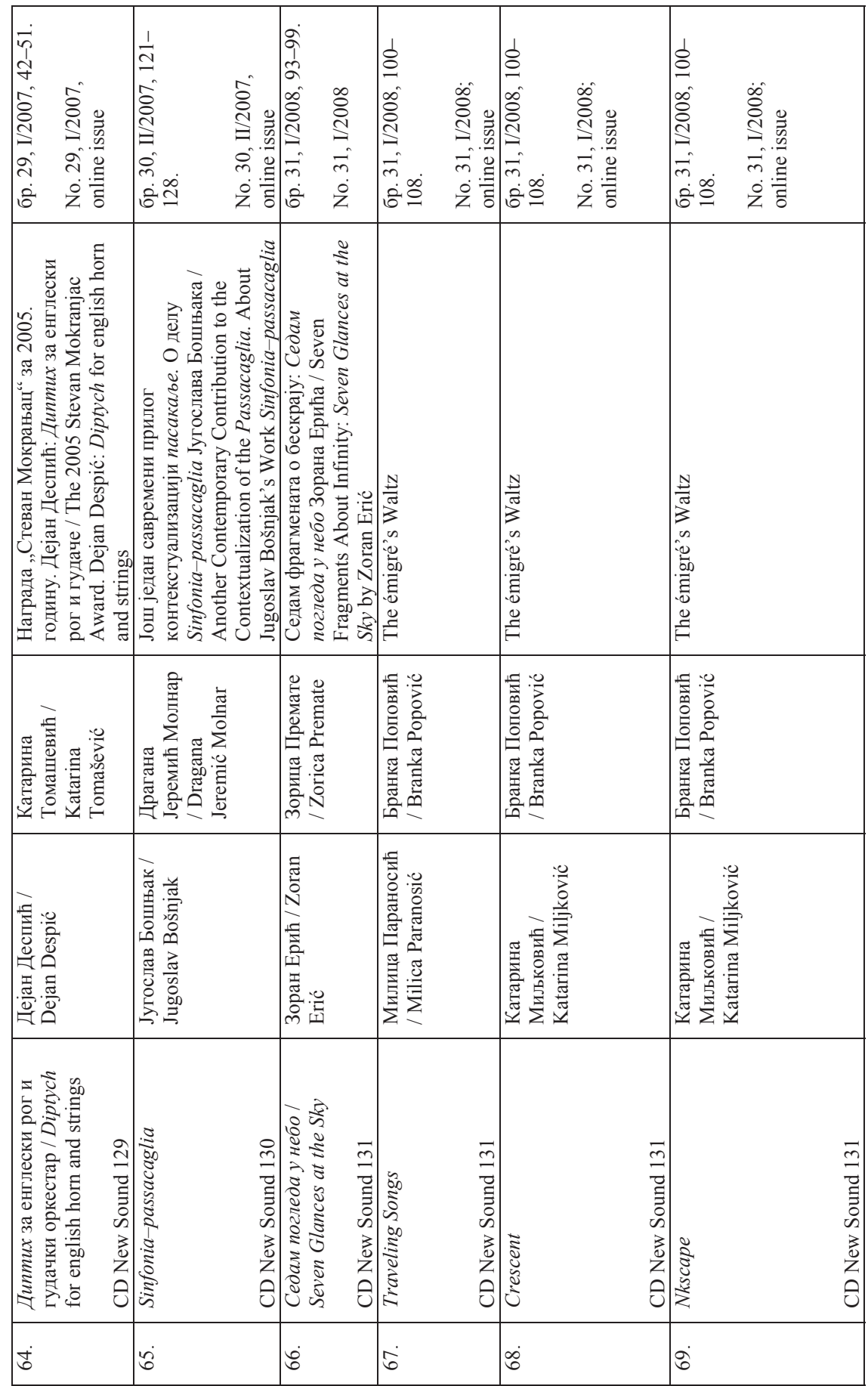


Veselinović-Hofman, M.: Sections New Works and Interpretations ... (114-145)

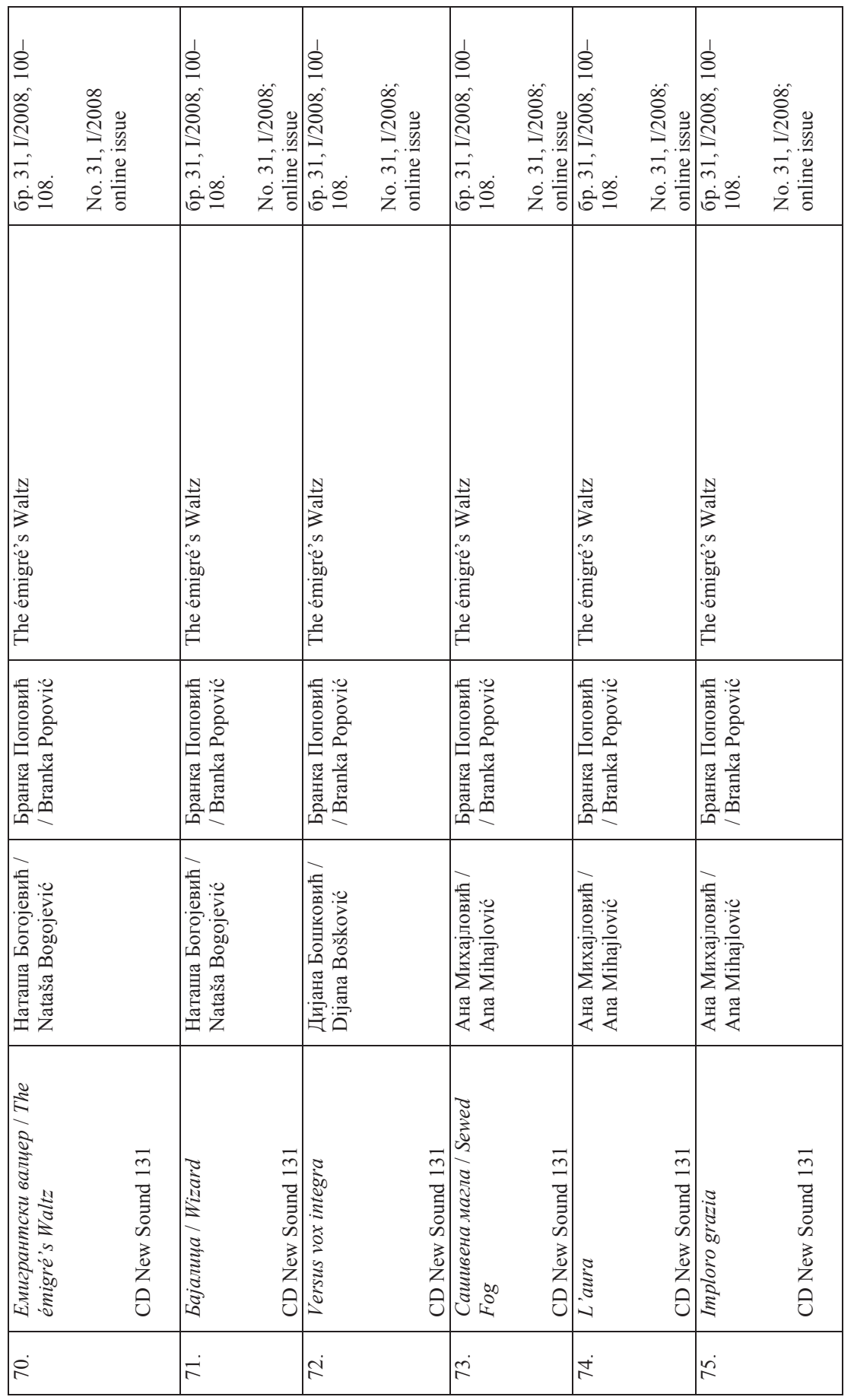




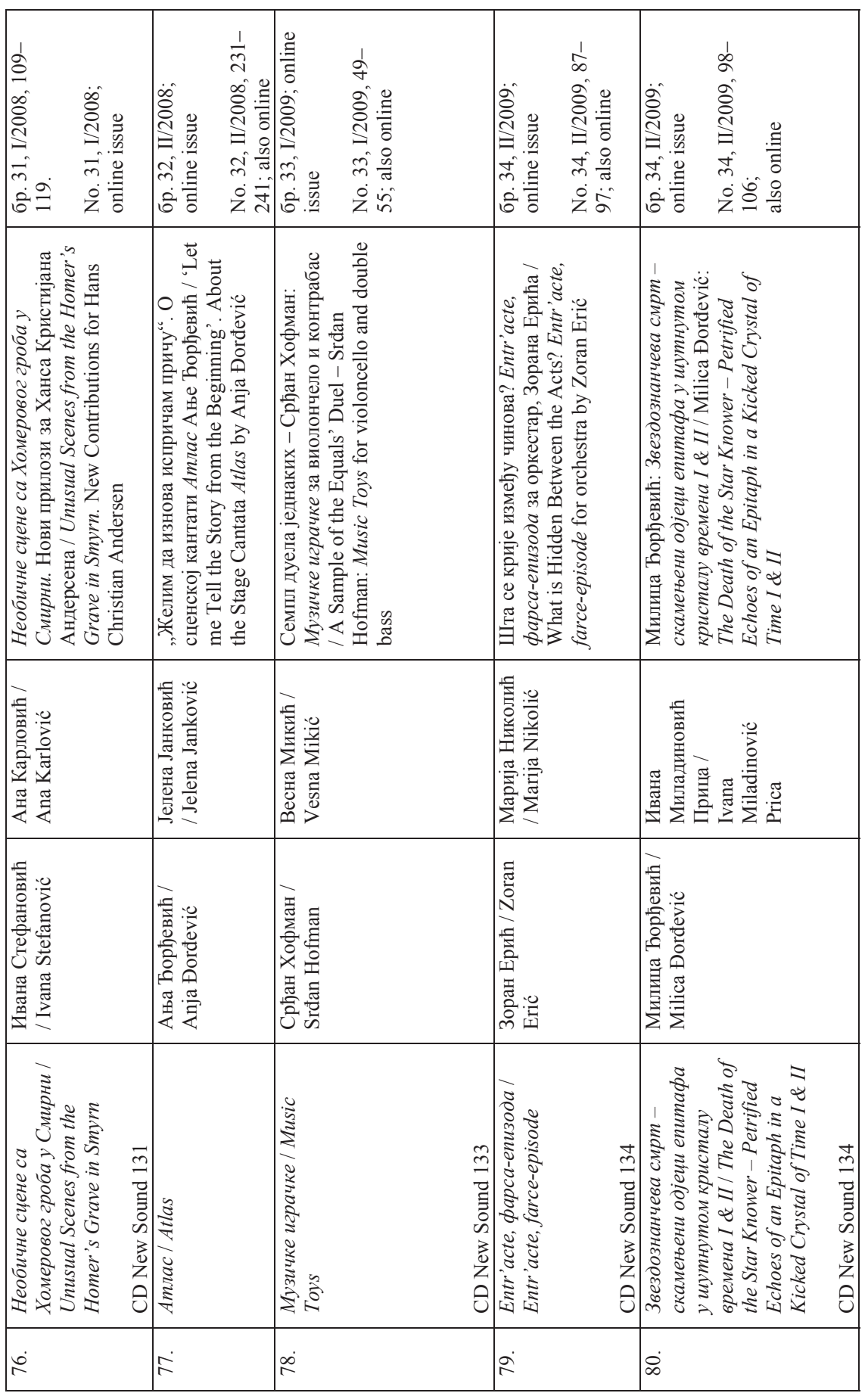


Veselinović-Hofman, M.: Sections New Works and Interpretations ... (114-145)

\begin{tabular}{|c|c|c|c|c|c|c|c|c|}
\hline 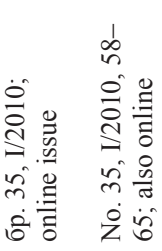 & & 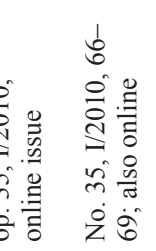 & 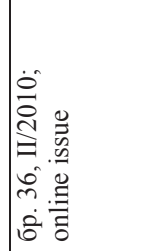 & 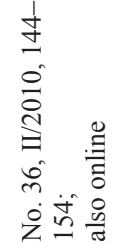 & 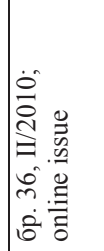 & 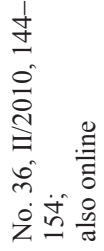 & 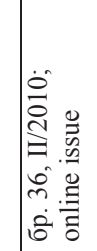 & 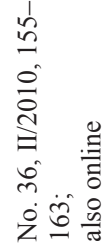 \\
\hline 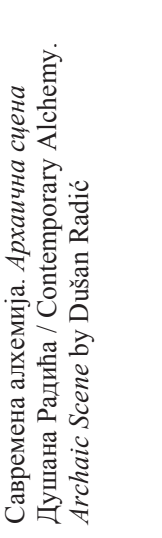 & & 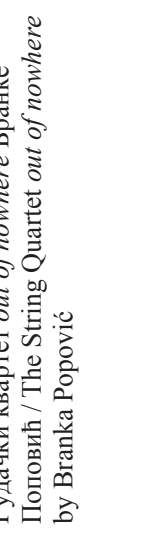 & 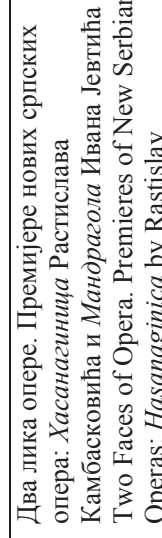 & 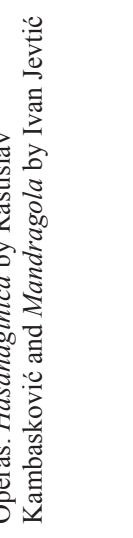 & 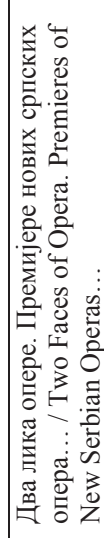 & & 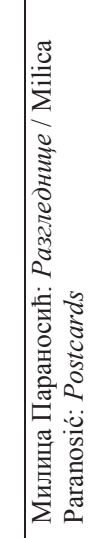 & \\
\hline 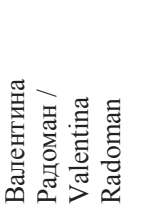 & & 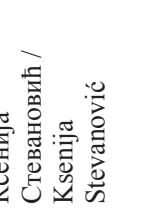 & 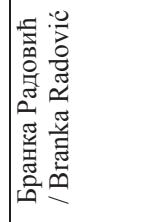 & & 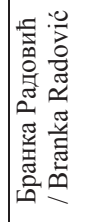 & & 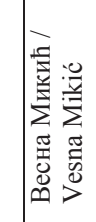 & \\
\hline 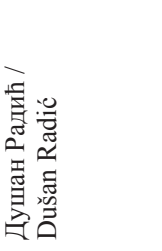 & & 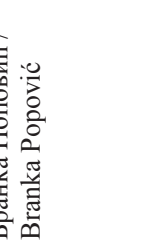 & 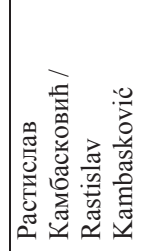 & & 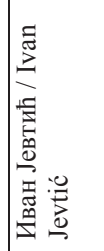 & & 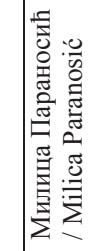 & \\
\hline 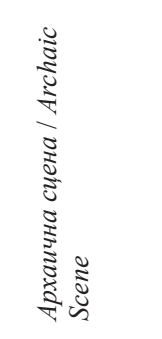 & 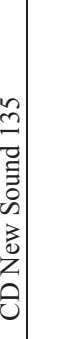 & 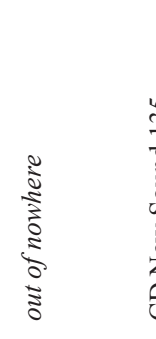 & 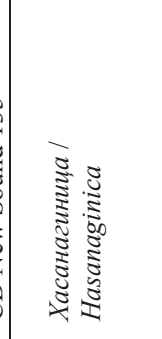 & 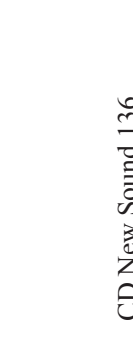 & 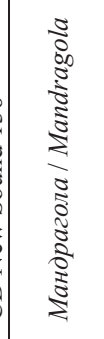 & & 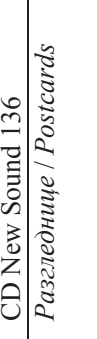 & 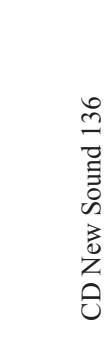 \\
\hline$\vec{\infty}$ & $\infty$ & dy & $\infty$ & & 市 & & $\ddot{\infty}$ & \\
\hline
\end{tabular}




\begin{tabular}{|c|c|c|c|}
\hline 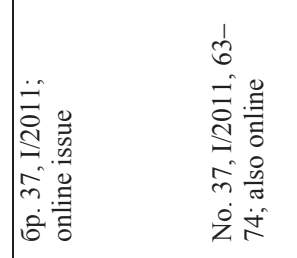 & 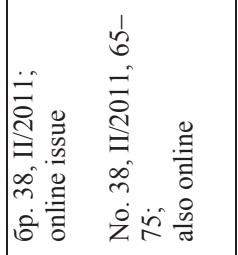 & 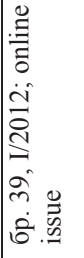 & 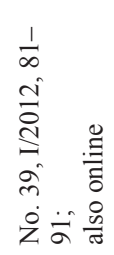 \\
\hline 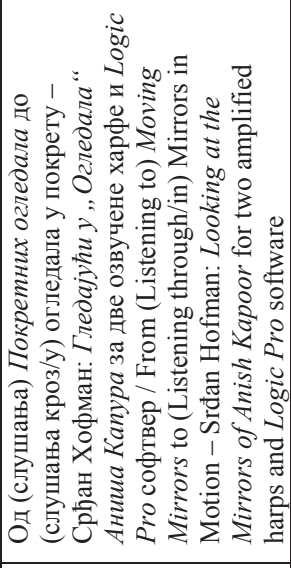 & 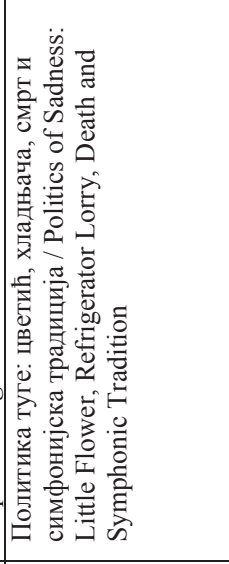 & \multicolumn{2}{|c|}{ 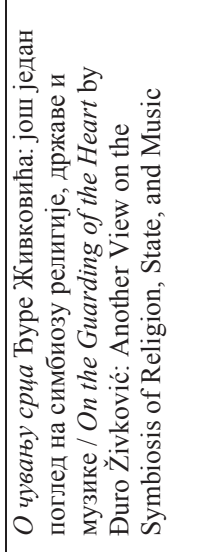 } \\
\hline 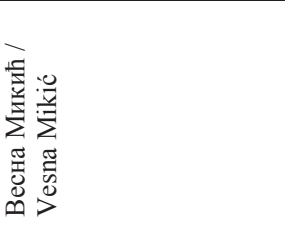 & 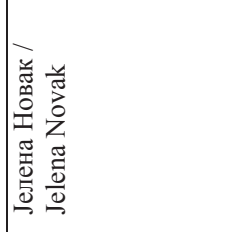 & \multicolumn{2}{|c|}{ 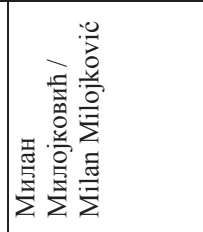 } \\
\hline 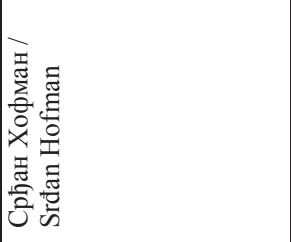 & 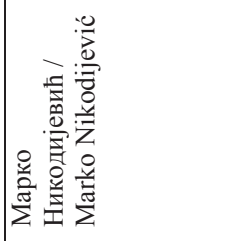 & \multicolumn{2}{|l|}{ 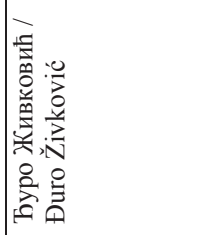 } \\
\hline 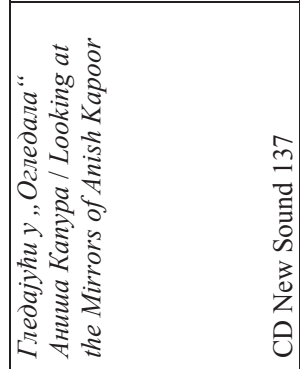 & 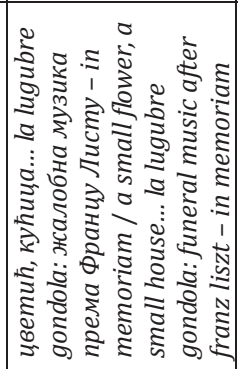 & 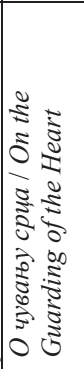 & 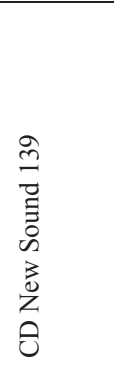 \\
\hline$\infty$ & $\infty$ & $\infty$ & \\
\hline
\end{tabular}


Veselinović-Hofman, M.: Sections New Works and Interpretations ... (114-145)

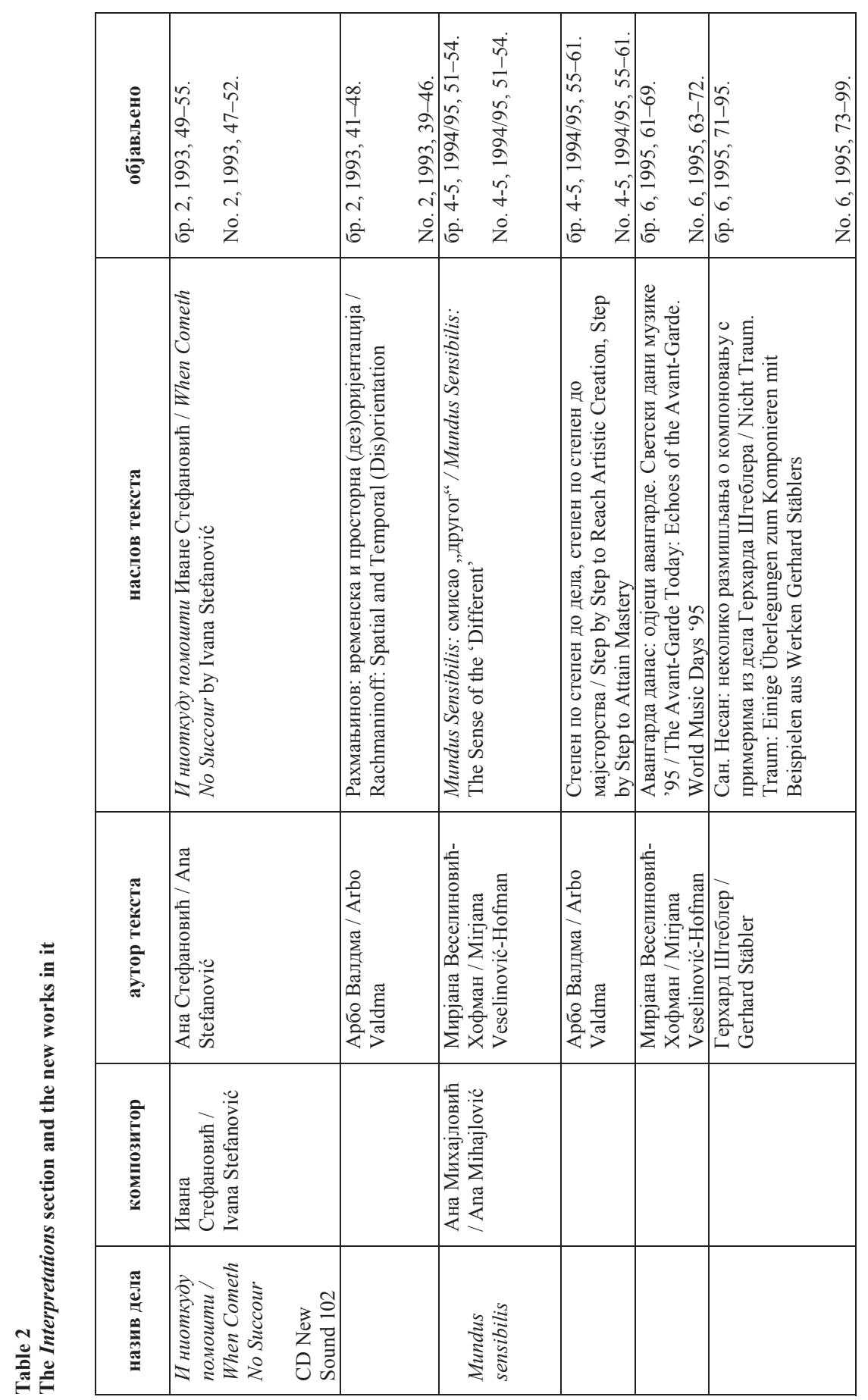




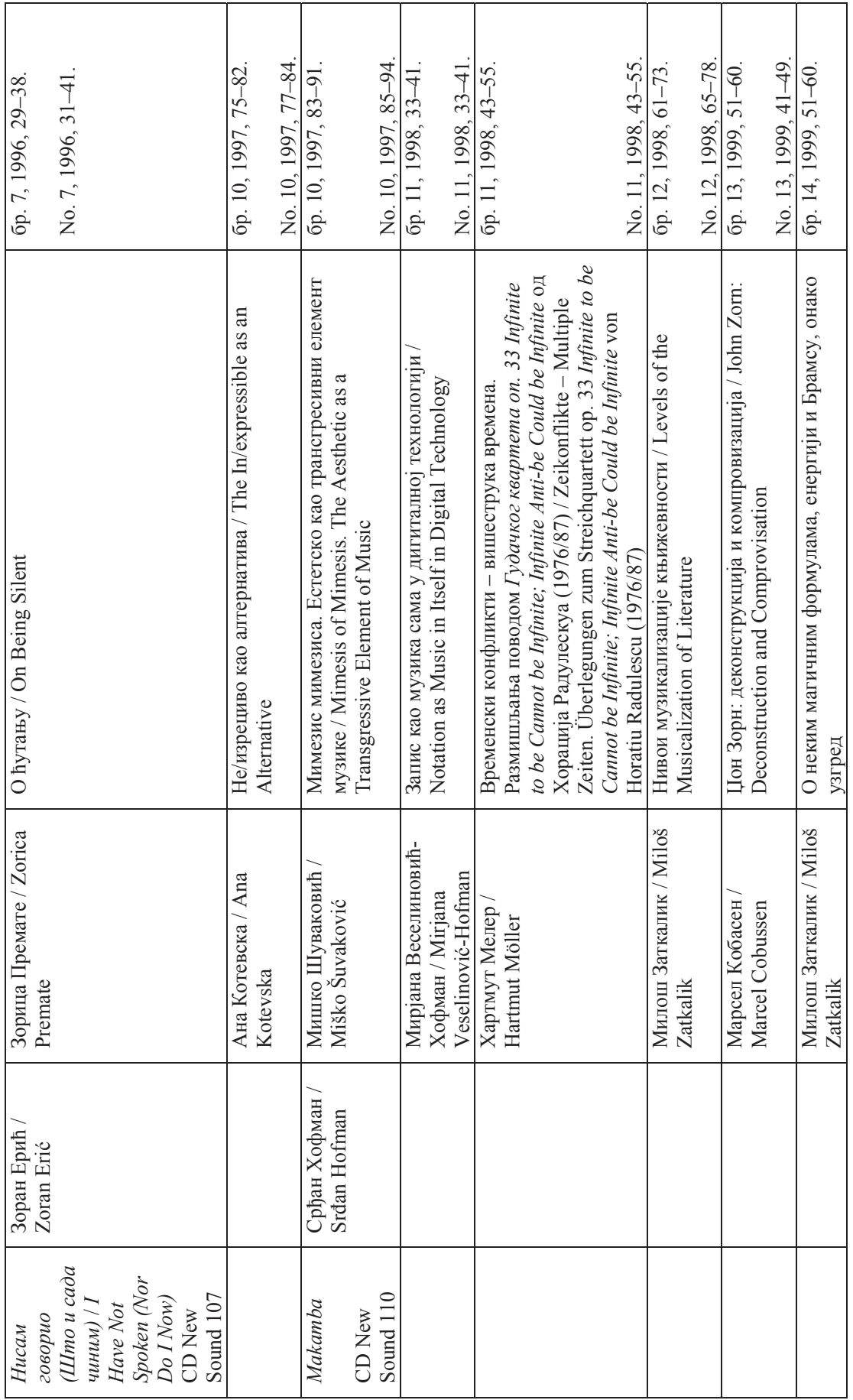




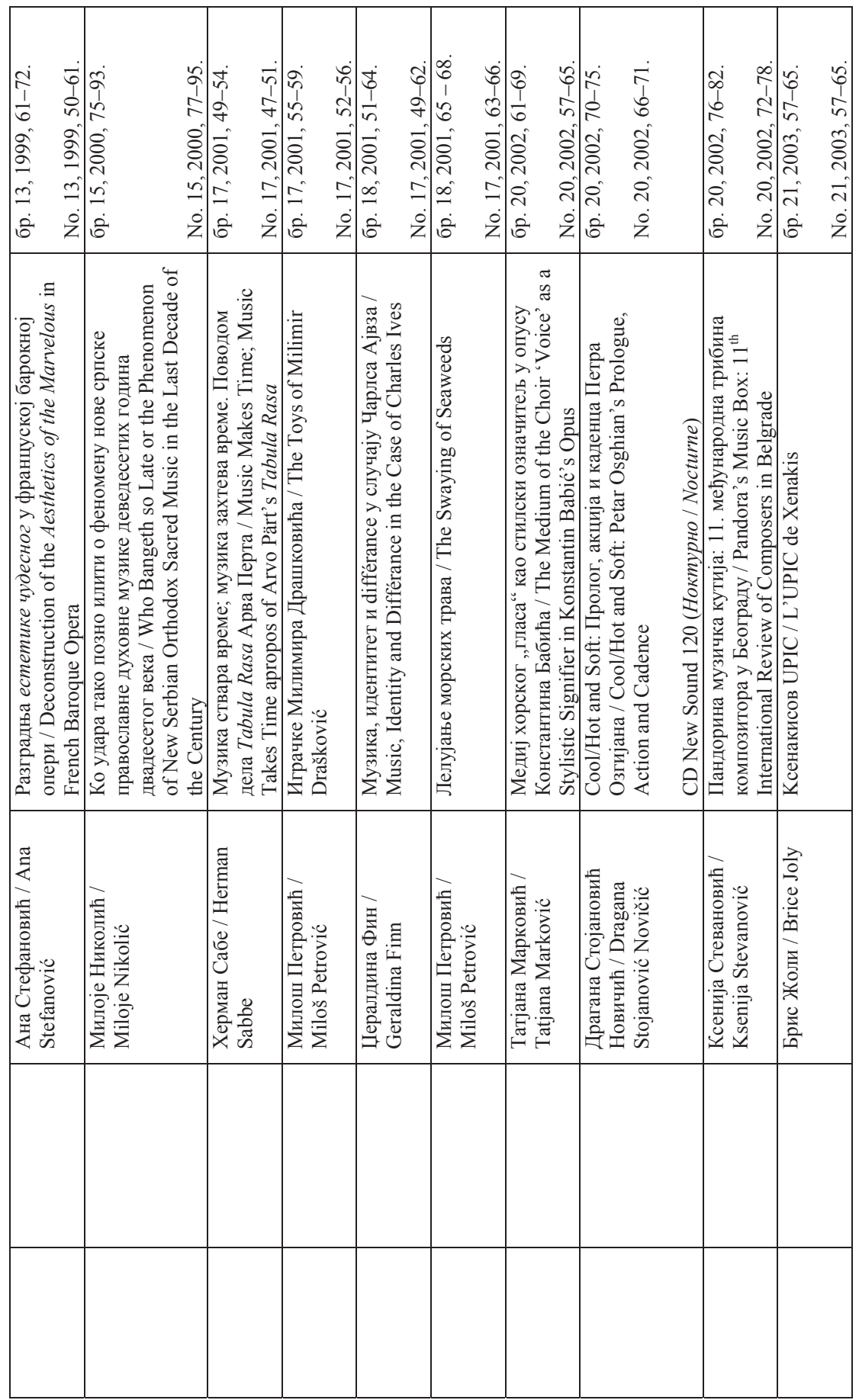




\begin{tabular}{|c|c|c|c|c|c|c|c|}
\hline 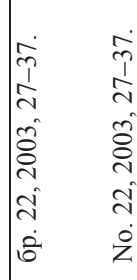 & 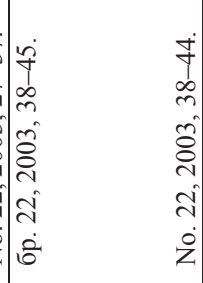 & 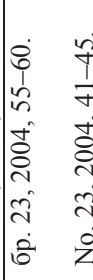 & 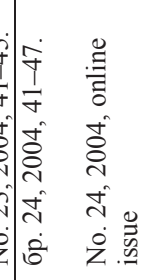 & 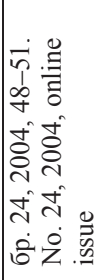 & 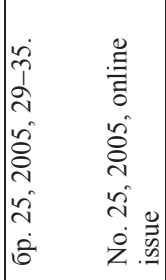 & 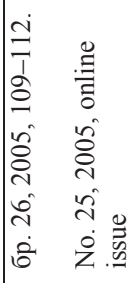 & 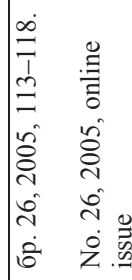 \\
\hline 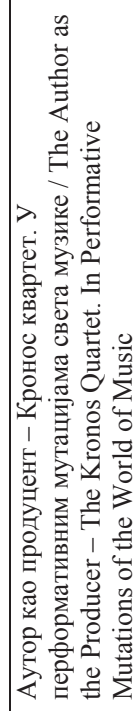 & 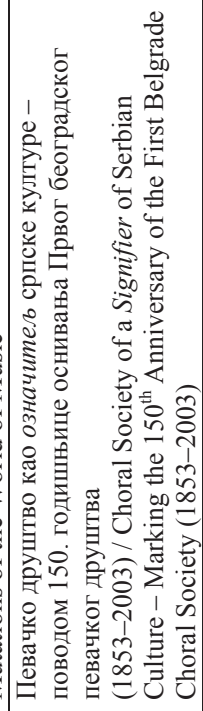 & 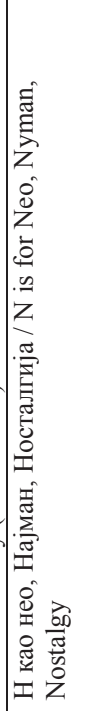 & 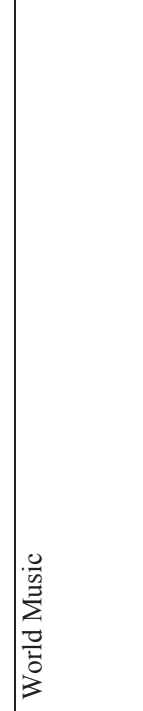 & 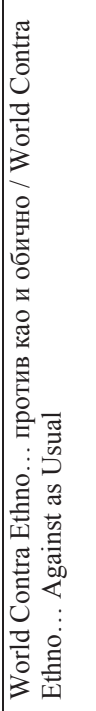 & 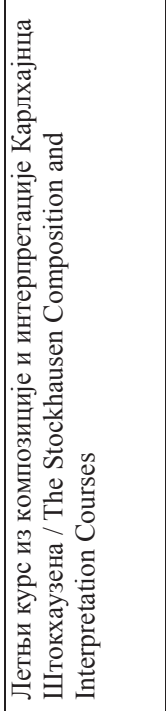 & 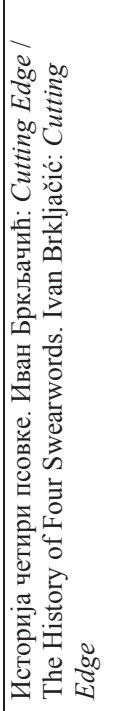 & 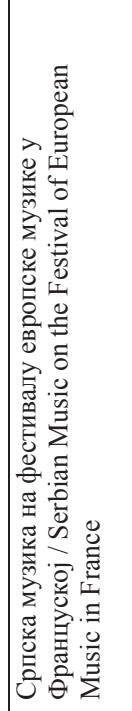 \\
\hline 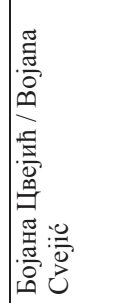 & 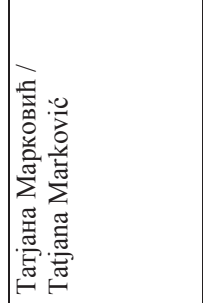 & 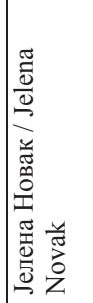 & 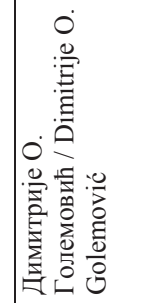 & 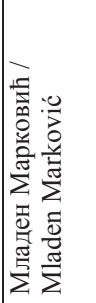 & 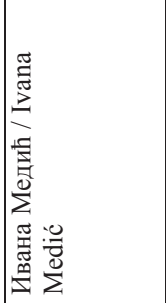 & 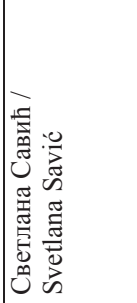 & 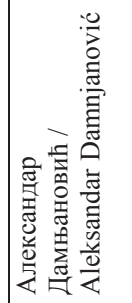 \\
\hline & & & & & & 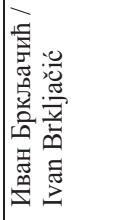 & \\
\hline & & & & & & 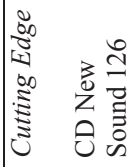 & \\
\hline
\end{tabular}


Veselinović-Hofman, M.: Sections New Works and Interpretations ... (114-145)

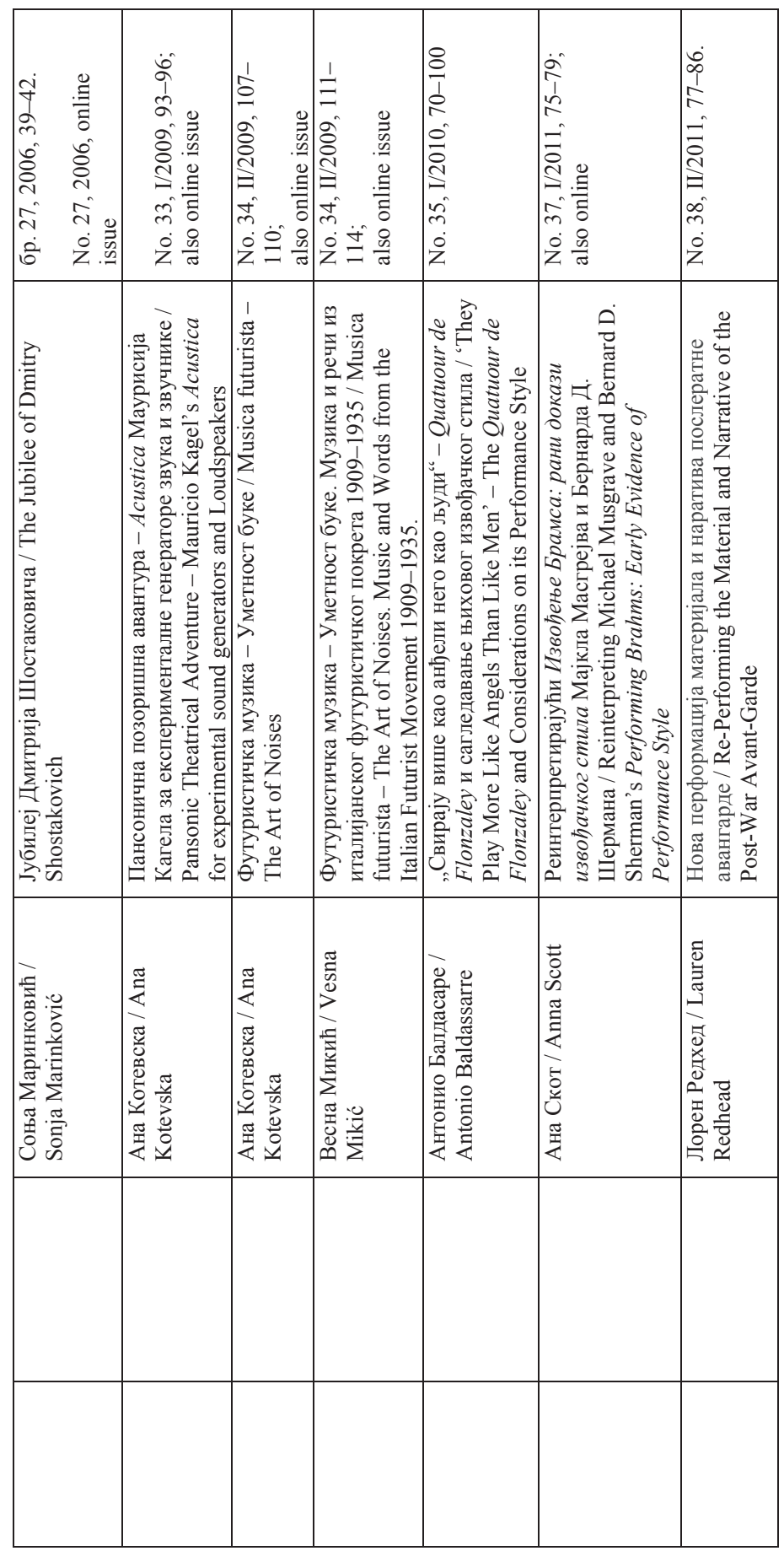




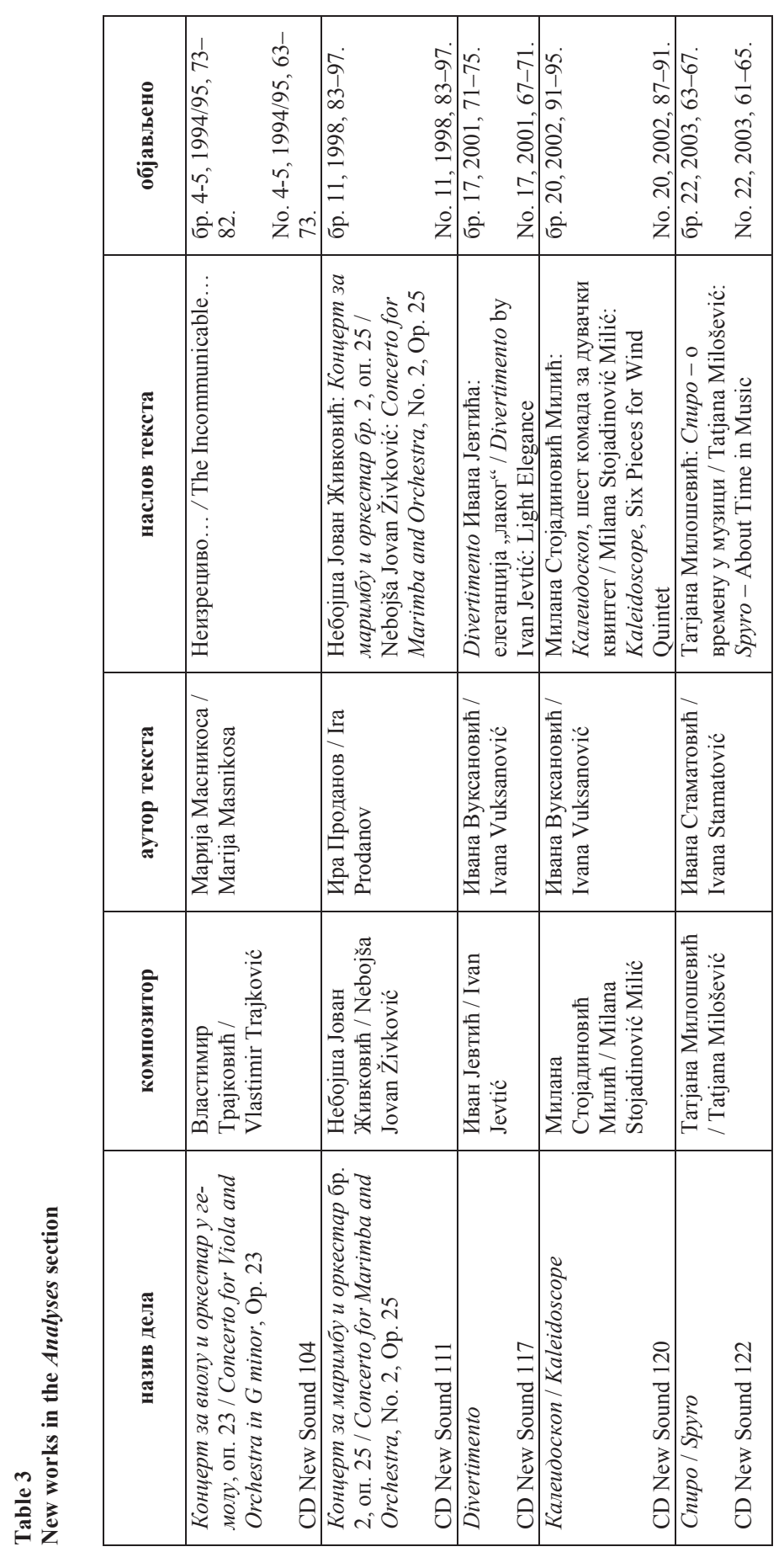


Veselinović-Hofman, M.: Sections New Works and Interpretations ... (114-145)

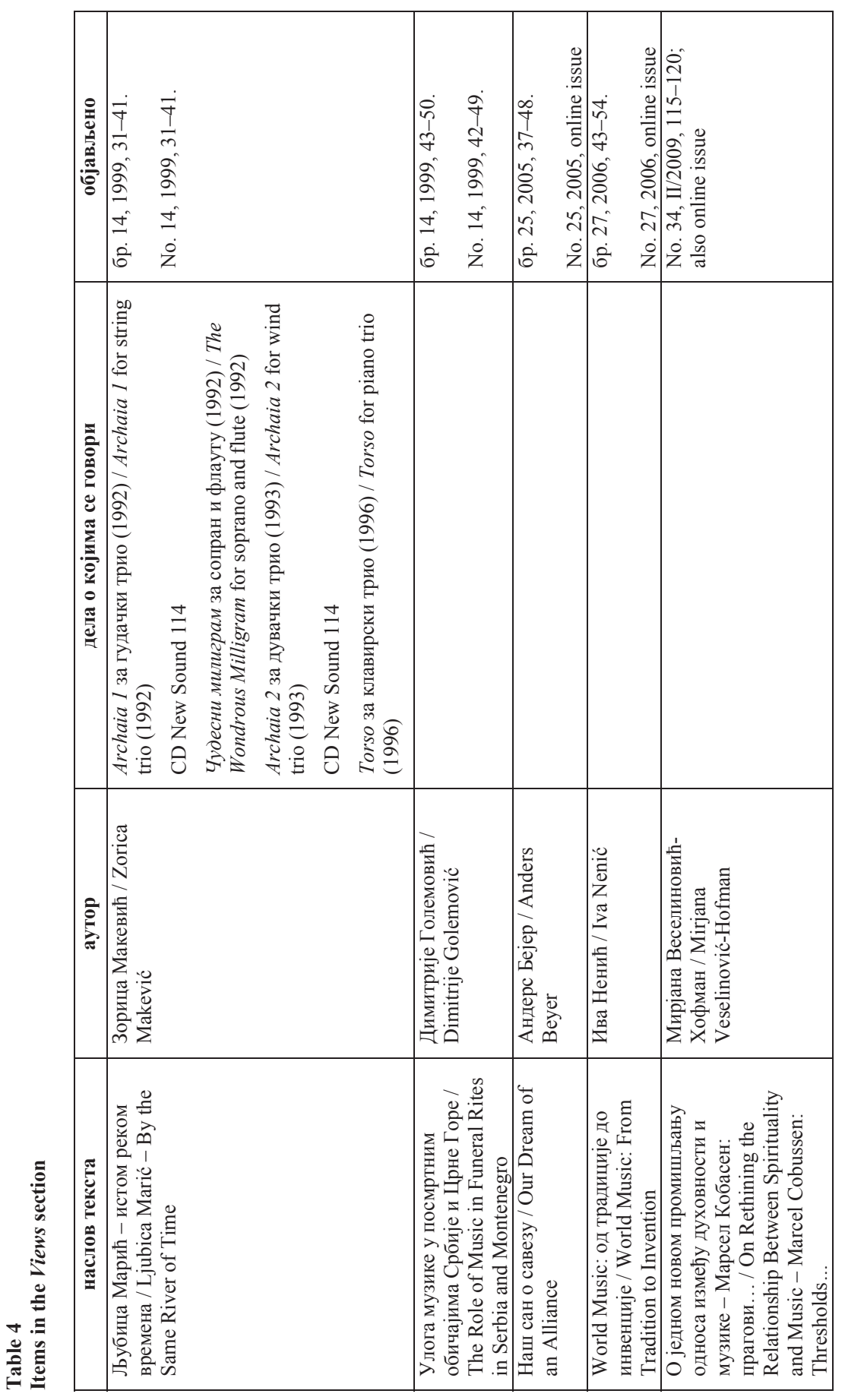

